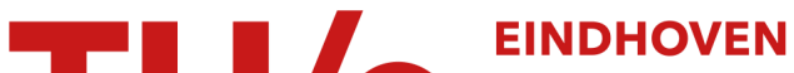 UNIVERSITY OF TECHNOLOGY
}

\section{Silk fibroin as biomaterial for bone tissue engineering}

\section{Citation for published version (APA):}

Melke, J., Midha, S., Ghosh, S., Ito, K., \& Hofmann, S. (2016). Silk fibroin as biomaterial for bone tissue engineering. Acta Biomaterialia, 31, 1-16. https://doi.org/10.1016/j.actbio.2015.09.005

DOI:

10.1016/j.actbio.2015.09.005

Document status and date:

Published: 01/02/2016

\section{Document Version:}

Accepted manuscript including changes made at the peer-review stage

\section{Please check the document version of this publication:}

- A submitted manuscript is the version of the article upon submission and before peer-review. There can be important differences between the submitted version and the official published version of record. People interested in the research are advised to contact the author for the final version of the publication, or visit the $\mathrm{DOI}$ to the publisher's website.

- The final author version and the galley proof are versions of the publication after peer review.

- The final published version features the final layout of the paper including the volume, issue and page numbers.

Link to publication

\section{General rights}

Copyright and moral rights for the publications made accessible in the public portal are retained by the authors and/or other copyright owners and it is a condition of accessing publications that users recognise and abide by the legal requirements associated with these rights.

- Users may download and print one copy of any publication from the public portal for the purpose of private study or research.

- You may not further distribute the material or use it for any profit-making activity or commercial gain

- You may freely distribute the URL identifying the publication in the public portal.

If the publication is distributed under the terms of Article $25 \mathrm{fa}$ of the Dutch Copyright Act, indicated by the "Taverne" license above, please follow below link for the End User Agreement:

www.tue.nl/taverne

Take down policy

If you believe that this document breaches copyright please contact us at:

openaccess@tue.nl

providing details and we will investigate your claim. 


\section{Accepted Manuscript}

Review article

Silk fibroin as biomaterial for bone tissue engineering

Johanna Melke, Swati Midha, Sourabh Ghosh, Keita Ito, Sandra Hofmann

PII:

S1742-7061(15)30098-2

DOI: http://dx.doi.org/10.1016/j.actbio.2015.09.005

Reference: ACTBIO 3870

To appear in:

\section{Acta Biomaterialia}

Received Date: $\quad 13$ June 2015

Revised Date: $\quad 24$ August 2015

Accepted Date: $\quad 6$ September 2015

Please cite this article as: Melke, J., Midha, S., Ghosh, S., Ito, K., Hofmann, S., Silk fibroin as biomaterial for bone tissue engineering, Acta Biomaterialia (2015), doi: http://dx.doi.org/10.1016/j.actbio.2015.09.005

This is a PDF file of an unedited manuscript that has been accepted for publication. As a service to our customers we are providing this early version of the manuscript. The manuscript will undergo copyediting, typesetting, and review of the resulting proof before it is published in its final form. Please note that during the production process errors may be discovered which could affect the content, and all legal disclaimers that apply to the journal pertain. 


\title{
Silk fibroin as biomaterial for bone tissue engineering
}

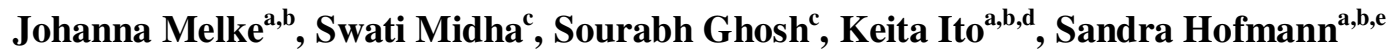

a: Orthopaedic Biomechanics, Department of Biomedical Engineering, Eindhoven University of Technology, PO Box 513, 5600 MB Eindhoven, The Netherlands

b: Institute for Complex Molecular Systems, Eindhoven University of Technology, PO Box 513, 5600

MB Eindhoven, The Netherlands

c: Department of Textile Technology, Indian Institute of Technology Delhi, Hauz Khas, New Delhi 110016, India

d: Department of Orthopaedics, UMC Utrecht, PO Box 85500, 3508 GA Utrecht, The Netherlands e: ETH Zurich, Institute for Biomechanics, Vladimir-Prelog-Weg 3, HCI E355.1, CH-8093 Zurich, Switzerland

Corresponding Author: Sandra Hofmann (Tel. +31 40-247 3494)

\section{E-Mail:}

Johanna Melke: j.melke@tue.nl

Swati Midha: swati.mid@gmail.com

Sourabh Ghosh: sghosh08@textile.iitd.ac.in

Keita Ito: K.Ito@tue.nl

Sandra Hofmann: S.Hofmann.Boss@tue.nl 


\section{Content}

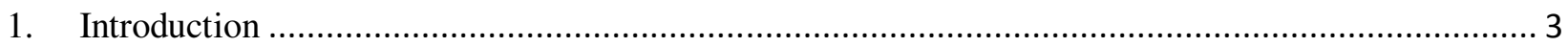

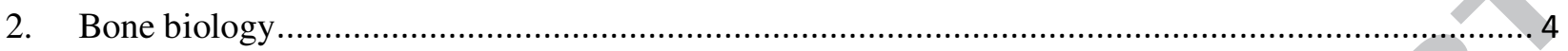

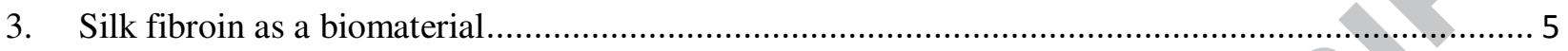

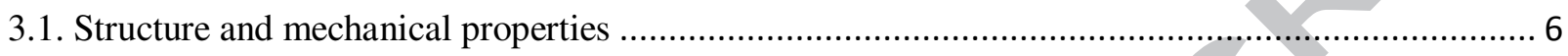

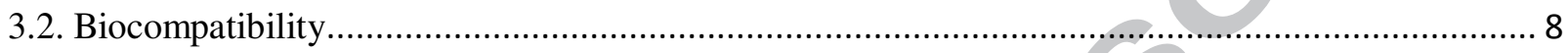

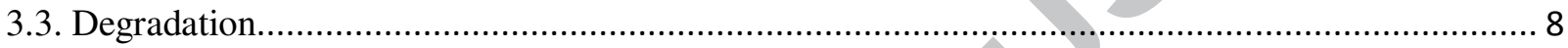

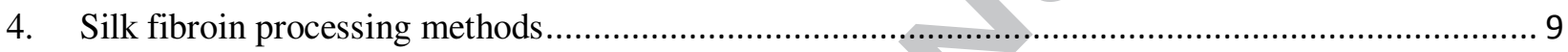

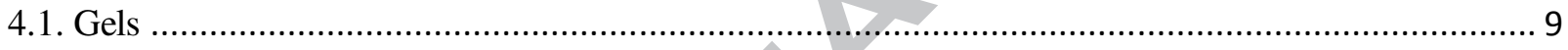

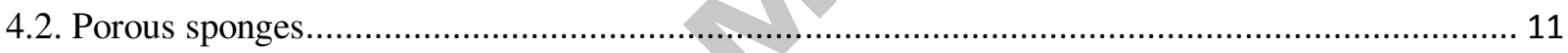

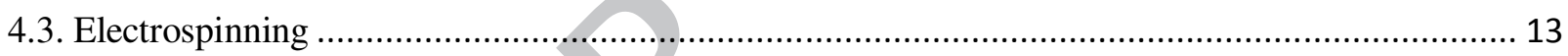

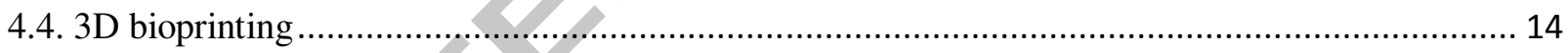

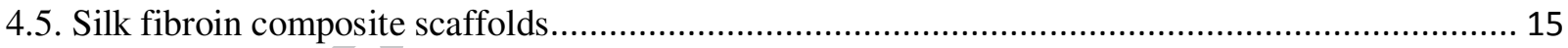

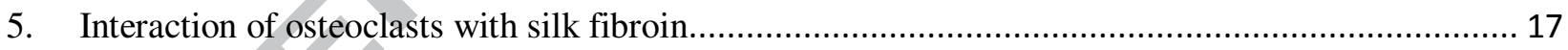

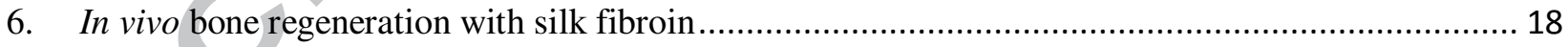

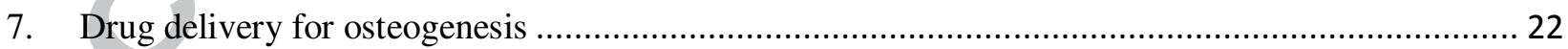

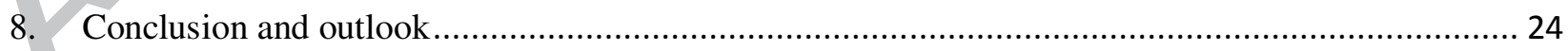




\begin{abstract}
Silk fibroin (SF) is a fibrous protein which is produced mainly by silkworms and spiders. Its unique mechanical properties, tunable biodegradation rate and the ability to support the differentiation of mesenchymal stem cells along the osteogenic lineage, have made SF a favorable scaffold material for bone tissue engineering. SF can be processed into various scaffold forms, combined synergistically with other biomaterials to form composites and chemically modified, which provides an impressive toolbox and allows SF scaffolds to be tailored to specific applications. This review discusses and summarizes recent advancements in processing $\mathrm{SF}$, focusing on different fabrication and functionalization methods and their application to grow bone tissue in vitro and in vivo. Potential areas for future research, current challenges, uncertainties and gaps in knowledge are highlighted.
\end{abstract}

Keywords: Bone tissue engineering, silk fibroin, regenerative medicine, drug delivery, scaffold

\title{
1. Introduction
}

Bone tissue engineering (TE) is a promising strategy to regenerate bone and is regarded as a future alternative to current clinical treatments. Not only can tissue engineered constructs be transplanted as a graft, but also pave the way for three-dimensional (3D) tissue models which help to investigate tissue abnormalities and to analyze them both at the cellular and molecular level [1,2]. In this whole process, the patient's own cells could be used which would be a key tool for personalized medicine. The goal is to create 3D bone tissues by combining cells, scaffolds and to some extent also growth factors or mechanical stimuli. One of the main challenges is the choice of an appropriate biomaterial which can mimic the natural bone tissue matrix with its mechanical and biological characteristics to support tissue development. Various materials have been tested for bone TE purposes [3,4]. Silk fibroin (SF) has been proven to be a promising biomaterial for scaffold fabrication in general and its remarkable mechanical properties predestine it for bone TE applications [5]. There is a steady increase in number of publications and citations on the use of SF as scaffold material for bone TE applications over the last 10 years which 
supports its significance and potential as a biomedical material for bone TE. This review seeks to highlight its characteristics and the various modification options of SF as a biomaterial in bone TE.

\section{Bone biology}

Bone TE relies on our knowledge of bone structure, composition, mechanics and tissue formation which makes it crucial to have a fundamental understanding of bone biology. Approximately $35 \%$ of the bone tissue is made of an organic part while the remaining $65 \%$ is inorganic matrix [6]. The organic extracellular matrix (ECM) of bone consists of complex self-assembled macromolecules such as collagens, which make up 90-95\% of the organic ECM, osteocalcin, osteopontin, osteonectin, bone sialoprotein, hyaluronan and proteoglycans [7]. The inorganic mineral phase of bone consists of hydroxyapatite (HA) as well as carbonate and inorganic salts [8]. Guiding stem cells along the osteogenic lineage is a critical step in bone regeneration and it is well known that the ECM plays a main role in regulating the stem cell fate [9-11]. Not only does this network serve as a scaffold for cells; it also helps in immobilizing growth factors and cytokines [12]. The water content in cortical bone can vary between 18 to $30 \%$ and shows a direct relationship to bone porosity, which increases through aging and osteoporosis [13]. Nano-composite structures made of collagen and HA contribute to the strength and hierarchical architecture of bone [14]. The overall bone structure is divided into cortical bone, which is more compact, and cancellous bone, which appears more sponge-like and whose pores are filled with bone marrow or fat. Bone is a highly dynamic tissue which is continually renewed and remodeled through formation and resorption processes of bone-forming osteoblasts and bone-resorbing osteoclasts as an adaption to mechanical loads, regulatory factors such as hormones and cytokines, and other environmental parameters [15]. Osteoclasts are multinucleated cells derived from hematopoietic stem cells [16], which dissolve crystalline HA through release of hydrochloric acid and a mixture of proteases which degrades the organic bone matrix rich in collagen fibers [17]. Their role in bone remodeling involves the removal of cracks after fracture or micro damage occurs but they also function as immune cells and can secrete cytokines that can affect surrounding cells $[18,19]$. Their differentiation and function is controlled by 
osteoprotegerin, receptor activator of nuclear factor (NF)-kappaB (RANK) and RANK ligand (RANKL) [20]. Osteoblasts are derived from mesenchymal stem cells (MSCs) located in the bone marrow and differentiate towards the osteogenic lineage [21]. Once they become encapsulated within their own matrix, they acquire a stellate morphology and are referred to as osteocytes [22,23]. Osteocytes comprise more than $90 \%$ of all bone cells in adult animals and are considered to be the major cell type responsible for sensing mechanical strain and translating it into biochemical responses which affect bone remodeling [24]. In vivo, osteocytes communicate to adjacent osteocytes via a dense and interconnected canalicular network containing cell processes for rapid signal transduction [25]. When mechanically activated, they produce bone morphogenetic proteins, Wnts, prostaglandin $\mathrm{E}_{2}$ and nitric oxide, which can modulate the recruitment, differentiation, and activity of osteoblasts and osteoclasts [26-30]. This ability makes osteocytes the essential mediator in orchestrating bone remodeling in response to mechanical stimulation [31]. MSCs are a valuable cell source for tissue regeneration because of their ability to self-renew and to differentiate along the osteogenic lineage [32]. Their recruitment, homing and subsequent differentiation also plays an important role in the repair of bone fractures [33]. Readily accessible sources of adult MSCs are bone marrow, adipose tissue or peripheral blood, of which bone marrow mesenchymal stem cells (BMSCs) have been most studied [34]. BMSCs can be expanded in vitro to 50 population doublings [35] which allows to increase their number such that a sufficient amount can be prepared for terminal differentiation and tissue regeneration.

\section{Silk fibroin as a biomaterial}

The behavior of cells which adhere to a surface is strongly influenced by the biomaterial characteristics. Molecular structure, mechanical properties and surface topography on micrometer and nanometer scale will influence adhesion, migration, proliferation, differentiation, and cell signaling [10,36-42]. In addition to soluble factors, sensing a biomaterial's physical properties plays a decisive role in cellular function and fate. The following paragraph will address the biomaterial characteristics of SF. 


\subsection{Structure and mechanical properties}

Silk is composed of two major proteins: SF (fibrous protein) and sericin (globular protein). SF is a protein isolated from different animals in the form of an aqueous protein solution. The ability to produce silk has evolved multiple times among insects such as B. mori, spiders, mites and beetles with diverse functions [43]. With such a variety of silk, it is not surprising that its molecular composition and structure can vary among the different species. SF of B. mori, the african wild silk moth Gonometa postica and G. rufobrunnea were compared amongst each other and revealed a significantly higher amount of polar (serine), acidic (aspartic acid) and basic (arginine) amino acids in Gonometa SF which can influence cell attachement and also alter chemical reacitivty for side chain modifications [44]. Indian tropical tasar silk of Antheraea mylitta or chinese oak tasar silk of A. pernyi, possess Arginine-glycine-aspartic acid (RGD) motifs in their amino acid sequences which is known to mediate cell attachment (reference: GenBank: AY136274.1, Submitted (on JUL-2002) to the EMBL/GenBank/DDBJ databases). There is a growing interest for silk from genetically engineered organisms. Monster Silk ${ }^{\mathrm{TM}}$ of Kraig Biocraft Laboratories, Inc., a composite fiber of spider silk proteins and silk from B. mori, is spun by transgenic silkworms. This chimeric silk has been reported to be stronger and more flexible than commercial grade silk [45]. Such diversities should also be taken into account as they can play a role in scaffold fabrication and the ultimate cell response in TE applications. Most studies so far have focused on SF from B. mori as it has been used for textiles over thousands of years and most of our knowledge on how to process silk is from this species. It is also easy to obtain in large quantities. Therefore only few studies have investigated the biomedical application of genetically engineered SF or SF from other species.

Conventionally, one of the first steps in the fabrication of SF scaffolds is the removal of the sericin component. Allergic reactions to silk have been reported that were attributed to sericin, which first resulted in its exclusion from biomedical applications [46-49]. However, it seems that these adverse reactions were caused by the combination of sericin and fibroin as mere sericin got established as a biocompatible material in the last years [50,51]. The glue-like protein sericin which coats fibroin, is removed by a thermochemical treatment of the cocoons, also known as degumming. In the degumming 
process, cocoons of B. mori are immersed in boiling water, sometimes with salt or detergent to increase the efficiency, which leaves the fibroin fibers behind. The SF amino acids sequence consists of two different subunits, a light and a heavy chain, which are connected through a disulfide bond. On both chains, the glycoprotein P25 is noncovalently attached to a set of 6 light and heavy chains $[52,53]$. While the light chain consist of a non-repetetive, more hydrophilic sequence, the amino acid sequence of the heavy chain consists of repetitive hydrophobic blocks of Gly-Ala-Gly-Ala-Gly-Ser and repeats of GlyAla/Ser/Tyr dipeptides, which form 12 crystalline domains [54]. This high glycine content allows for a tight packing into extremely stable $\beta$-sheet nanocrystals, which can be induced e.g. by potassium phosphate or methanol treatment $[55,56]$. The crystalline domains have a header and terminal sequence and are linked by 11 spacers with $42-43$ residues each which are nearly identical [54]. The main molecular interactions in these crystalline $\beta$-sheets are hydrogen bonds. Even though they are one of the weakest known interactions, hydrogen bonds contribute greatly to the rigidity and tensile strength of silk. Through silk's nano-confinement, the crystals are loaded in uniform shear and rupture is followed by a slip-stick motion as the strand slides and reforms hydrogen bonds which leads to their most efficient use [57]. Reforming those weak hydrogen bonds gives SF the ability to self-assemble and self-heal. SF can selfassemble into larger fibrous structures which are characterized by a high degree of hierarchical molecular order and also their enhanced mechanical properties [58-60]. Silk of B. mori obtained in the laboratory by forced silking of silk worms has a young's modulus of 12.4-17.9 GPa and an ultimate tensile strength of $360-530 \mathrm{MPa}$ at an elongation of $18-21 \%$ [61]. Since the degumming process exposes silk to an unnatural environment, the SF structure and its mechanical properties change slightly. Removal of the water-soluble sericin protein coat from the cocoon yields degummed silk fibers with a similar Young's modulus but an altered tensile strength of 450 to $700 \mathrm{MPa}$ at an elongation of 12-24\% [62]. These remarkable mechanical characteristics and its high resistance to deformation make SF a favorable biomaterial for load bearing composites. However, the material properties of SF fibers cannot be directly compared with the processed scaffolds as their mechanical properties will vary depending on different parameters such as processing techniques, composition, matrix stiffness, $\beta$-sheet content as well as scaffold morphology and topoplogy. 


\subsection{Biocompatibility}

Due to its chemical composition and structure, silkworm SF has been shown to be highly biocompatible [63]. The role of SF as biomaterial was first assessed in 1995, showing the attachment and growth of fibroblast cells on B. mori SF matrices [64]. Years later it has been demonstrated that a negligible inflammatory response was exhibited with a high biocompatibility with blood [65-67]. SF has been recognized by the US Food and Drug Administration (FDA) as a biomaterial in 1993 and is widely used as suture material. Different silk-based medical devices have been approved by the FDA by now such as the long term bioresorbable surgical mesh Seriscaffold ${ }^{\circledR}$ and SeriACL ${ }^{\mathrm{TM}}$, a SF based ligament graft. Since silk can easily be absorbed by the human skin, it has been investigated as a biomaterial for wound dressing and products for clinical application are being developed (Akeso Biomedical Inc.) [68,69].

\subsection{Degradation}

Degradation plays an important role for biomaterials used in bone TE. Depending on the target tissue, scaffolds should degrade at a controlled degradation rate to support new bone formation. Therefore the controlled manipulation and understanding of degradation rates is one of the main goals in materials science. Being a protein, SF has been shown to be susceptible to proteolytic degradation by various enzymes such as protease XIV, alpha-chymotrypsin and collagenase IA [70,71]. Concerns have been raised about the degradation of the SF $\beta$-sheet structure since amyloid $\beta$-fibrils are associated to Alzheimer disease. However, SF degradation products showed no significant cytotoxicity to neuronal cells in in vitro assays [72]. As SF is being degraded, the resulting amino acids can be absorbed in vitro or in vivo which is favorable in biomedical applications. SF degradation can be influenced by the content of water-insoluble silk II and water soluble silk I structures, the former being induced e.g. during methanol treatment or stretching. With increasing silk II amount, and therefore increasing amount of $\beta$-sheet structures, the degradation time has been shown to increase as well [73]. A faster degradation of SF films was achieved by preparing water insoluble SF film with lower $\beta$-sheet content from a concentrated aqueous solution by either subsequent water-based annealing or a very slow, controlled drying process $[73,74]$. Of these two methods, SF films prepared by a slow drying process, showed the lowest $\beta$-sheet 
content which resulted in the fastest degradation [74]. The degradation behavior is also influenced by the SF source. When comparing SF from mulberry and non-mulberry silkworms, different degradation rates have been observed. Non-mulberry SF was less prone to degradation due to the compact crystal structure and high $\alpha$-helix and $\beta$-sheet contents [75]. However, so far only a few studies compared the degradation of SF among different species or genetically modified organisms which produce SF. Using transgenic silk fused with a matrix metalloproteinase (MMP-2) cleavage site, a faster degradation by matrix metalloproteinase-2 was achieved [76]. To slow down degradation, it was shown that protease inhibitors integrated into silk based systems, can decrease the degradation rate [77]. This enhanced regulation of degradation also opens up new possibilities for controlled drug release applications.

\section{Silk fibroin processing methods}

Not only the choice of scaffold material but also scaffold morphology - and with that the choice of the material processing method - is a decisive factor in bone TE. Scaffolds provide biomechanical support for cells until they are organized into a functional tissue through migration, proliferation, differentiation and deposition of extracellular matrix. Therefore they have to meet certain requirements. Three-dimensional scaffolds need to offer appropriate mechanical properties, pore size, pore orientation, porosity, interconnectivity and surface chemistry to promote the development of osteoblastic cells [78-81]. Also the influence of scaffold design parameters on the transport of nutrients and metabolic waste products has to be taken into account. The application of SF as sutures and wound dressings has inspired materials scientists to develop a wide range of SF scaffolds. SF can be processed into hydrogels, sponges, fibers, particles, microspheres, tubes and electrospun fiber mats with tunable properties to study cell-cell and cell-biomaterial interactions. The most relevant processing methods for bone TE (Table 1) will be discussed in the following sections.

\subsection{Gels}

Hydrogels are water-swollen three-dimensional polymer networks which provide remarkable options for the delivery of cells and cytokines in TE. Especially for clinical applications they are favorable as they 9 
offer the advantage of being injectable. The hydrogelation of SF is induced in aqueous SF solutions through high temperatures, low $\mathrm{pH}$, high ionic strength, vortexing, sonication, freeze gelation or electrogelation [82-86]. During the gelation process, structural changes of the SF occur from a disordered state to a $\beta$-sheet conformation which physically cross-links and stabilizes the gel [87]. Electrogelation is an exception as it leads to random structures and $\alpha$-helices rather than $\beta$-sheets and is temperature reversible [88]. Also sonication-induced gelation can be reversed to some extent. Sonication imparts local vibrational movement of SF macromolecules, which alters the hydrophobic interaction and facilitates selfassembly of SF macromolecules to form $\beta$-sheet crystals. After gelation, further sonication can convert the gel back into a solution due to the cleavage of disulfide bonds, modulation in hydrophobic inter- and intrachain interactions and $\beta$-sheet conformations [89]. However, a gel is formed again shortly after the sonication stops. SF hydrogels with interesting mechanical properties can be formed through freeze gelation techniques, which use a frozen regenerated SF solution that is immersed into a suitable solvent while being kept below its freezing temperature. After several hours, gelled scaffolds form [86]. SF cryogels were obtained from frozen SF solutions at subzero temperatures by adding ethylene glycol diglycidyl ether which induced $\beta$-sheet crystallization, inducing gelation. These gels exhibited remarkable mechanical properties such as an elasticity that allowed them to resist complete compression without any crack development (Figure 1B), while hydrogels formed at $50^{\circ} \mathrm{C}$ fractured already under low deformation (Figure 1A). Cryogel scaffolds produced from a 12.6\% SF solution showed a very high compressive modulus of $50 \mathrm{MPa}$ which makes them a potential scaffold for bone regeneration [90].

Sonication-induced SF hydrogels have been shown to successfully encapsulate human MSCs while supporting their proliferation, growth and cellular functions [84]. The aqueous SF solution was shortly sonicated, mixed with the hMSCs and then incubated at $37^{\circ} \mathrm{C}$ to allow for complete gelation. In a similar approach, hMSCs were encapsulated in a blend of SF and SF-poly-L-lysine. The hydrogel induced osteogenic differentiation of hMSCs even when no osteogenic stimulants were added to the cell culture medium [91]. Furthermore, injectable SF hydrogels have been demonstrated to accelerate the remodeling processes in rabbit distal femurs [92]. These osteogenic features were improved by using sonicationinduced SF hydrogels with incorporated vascular endothelial growth factor (VEGF) and bone 10 
morphogenic protein-2 (BMP-2). In vivo studies in rabbits demonstrated that VEGF and BMP-2 in these hydrogels promote angiogenesis and new bone formation, respectively, and that the combinations of those two factors had an additive effect on bone regeneration [93]. Such gels could be used to deliver various growth factors in a minimally invasive approach to regenerate irregular or poorly accessible cavities in bone. Finally, injectable fibrin network containing activated platelets have also been combined with SF. The resulting gel showed increased mechanical properties, slower degradation, and more controllable growth factor release of VEGF, platelet-derived growth factor and transforming growth factor beta 1 (TGF- $\beta 1$ ) as compared to control groups without SF [94]. It is known that platelet-rich plasma with bone grafts significantly improves the quality of bone [95-98]. Therefore, the combination of platelet-rich plasma with SF could be a beneficial bone TE strategy.

\subsection{Porous sponges}

Porous sponge-like scaffolds have been widely used in bone TE. Their 3D porous structure allows for cell attachment, proliferation, and migration, and facilitates nutrient and waste transport either by diffusion in a static environment or perfusion e.g. in bioreactor setups. The pores can be formed in different sizes using porogens, gas foaming or freeze-drying $[99,100]$. Processing parameters can be varied by using different solvents for regeneration of SF including organic solvents such as hexafluoro-2-propanol (HFIP) or aqueous solution. HFIP-SF scaffolds are relatively persistent towards degradation and may take up to two years to degrade in vivo. Whereas scaffolds derived from aqueous solutions can degrade completely in 2 to 6 months [101]. There are different opinions on which fabrication method is most suitable for bone TE. It was reported that HFIP-derived SF scaffolds pre-seeded with adipose-derived stem cells (ASCs), demonstrated a better bone tissue formation with increased levels of osteopontin, collagen type I, bone sialoprotein, increased calcium deposition and mineralized ECM volume. In this study, the amount of alkaline phosphatase (ALP) activity and calcium deposition after 7 weeks were comparable to cells cultured in decellularized trabecular bone [102]. However, different results were obtained using scaffolds with lyophilization-induced bone lamellar-like structure [103]. In this study, methanol treatment was compared to water annealing and steam sterilization for the induction of $\beta$-sheet structures. Cell culture of 
hMSCs under osteogenic conditions showed higher ALP levels as well as mineralized matrix after 42 days in scaffolds derived from aqueous solutions. Also, Kim et al. reported enhanced osteogenesis of hMSCs on water-based scaffolds as compared to HFIP-derived scaffolds after 28 days of culture [104]. It was also reported that aqueous-based SF scaffolds exhibited higher osteoconductivity compared to SF dissolved in HFIP when they were implanted into cortical defects of sheep. After 4 weeks of implantation, new trabecular bone formed inside the pores of the aqueous SF scaffold while the HFIP-SF scaffolds mainly contained necrotic cells and no trabecular bone [105]. It is argued that these observations might be associated with an increased surface roughness of the aqueous SF scaffolds at a micro-scale. This is probably due to the partial dissolution of the $\mathrm{NaCl}$ particle surface as well as different degradability and structural changes $[104,106]$.

Using porous SF scaffolds, it was shown that the osteogenic differentiation of hMSCs can be enhanced by a combination of low oxygen levels $(5 \%)$ and increased lysine and proline concentrations in the cell culture medium which altered the metabolic rate of the differentiating cells [107]. Changes in glucose consumption rate, lactate synthesis rate, and the use of lysine, proline, glutamate, and glutamine seemed to be coupled to osteogenesis of hMSCs. The progressing mineralization of ECM on RGD decorated SF scaffolds with small $(106-212 \mu \mathrm{m})$, medium $(212-300 \mu \mathrm{m})$, and large pore sizes $(300-425 \mu \mathrm{m})$ was demonstrated by weekly micro computed tomography $(\mu \mathrm{CT})$ imaging [108]. The scaffolds were seeded with hMSCs and cultured in bioreactors which allowed to aseptically scan the constructs repeatedly. The hMSCs were differentiated along the osteogenic lineage and produced bone-like tissue which resembled the initial scaffold geometries and featured trabecular-like structures (Figure 2). In a similar setup, it was shown that initial cell pre-cultivation can maximize ECM mineralization by hMSCs on SF scaffolds, but only with smaller pore diameters in the range of 112-224 $\mu \mathrm{m}$ [109].

In bone $\mathrm{TE}$, micro-CT imaging gives the opportunity of monitoring 3D mineralization without destroying the bone tissue engineered construct. However, when using SF as scaffold material, the underlying scaffold structure remains invisible as the material is not radio-opaque. SF scaffolds cannot be segmented from the cell culture medium after taking up water. Therefore it is not possible to monitor degradation processes or to investigate the influence of single scaffold structures on ECM mineralization over time. 
Several studies have shown that porous SF scaffolds can mineralize spontaneously in the presence of culture media, which strongly affects the comparability of studies analyzing how cells form bone-like tissue $[110,111]$. The choice of FBS has been shown to be a decisive factor in this process for both acellular and cell-seeded SF scaffolds [112]. Many theories concerning the mineralizing mechanism of SF have been put forth. Vetsch et al. have attributed the inherent mineralization of silk to the abundant $\beta$ sheet crystalline regions present in the structure which act as nucleating sites to facilitate HA deposition, similar to the mineralizing mechanism of collagen in native bone tissues [112]. On the other hand, there is evidence that the amorphous linkages within the $\beta$-sheets of SF, which resemble the anionic, noncollagenous proteins, facilitate the deposition of HA on these nucleation sites [113]. The hypothesis was supported by in vitro evidence showing extensive apatite formation only in the low molecular weight (2$10 \mathrm{kDa}$ ), electronegative fragments of the fibroin chain. Another supporting study by Jung et al. has demonstrated enhanced mineralization on such hydrophilic, electronegative fragments of SF by seeded hMSCs [114]. Furthermore, this pro-osteogenic property of the low molecular weight fibroin fragments has been attributed to the suppression of the Notch signaling pathway [114].

Improved mineralization in vitro and in vivo was observed with genetically modified SF which had a polyglutamic acid site and was produced in transgenic silkworms through systematic transformation [115]. In bone, mineralization occurs by self-assembly at the charged acidic domains of non-collagenous proteins $[116,117]$. Upon implantation of these modified, porous scaffolds into epicondyle defects in rabbit femurs, mineralization and bone formation occurred earlier as compared to native SF scaffolds.

\subsection{Electrospinning}

Electrospinning allows for the production of polymer fibers with diameters on a micrometer and nanometer scale which are able to mimic nanoscale properties of fibrous ECM components. It is a simple and inexpensive process as its setup consists only of a syringe pump, a high voltage source, and a collector. With this technique, fine mats from B. mori SF with a fiber diameter of less than $800 \mathrm{~nm}$ were formed by electrospinning with polyethylenoxide [118]. Electrospinning with formic acid as solvent resulted in fibers with an average diameter of $80 \mathrm{~nm}$ [119]. Cell culture experiments showed that after 14 
days of incubation, the electrospun SF mats supported extensive BMSC proliferation and matrix coverage [108]. To mimic the ECM for TE applications, a 3D environment is desirable. The importance of this was shown by the use of electrospun 3D SF scaffold which increased the adhesion and proliferation of preosteoblasts and the ALP activity of osteoblasts [121]. In vivo studies in rats demonstrated an increased bone regeneration in $3 \mathrm{D}$ porous electrospun $\mathrm{SF}$ scaffolds compared to non-porous controls and commercially available porous three-dimensional polylactic acid (PLA) scaffolds [122]. It is assumed that the 3D fibrous structure provides a more natural surface for cell adhesion and allows easier circulation of nutrients and waste compared to sponge-like structures which only offer a 2-D surface in a microscopic view and usually have lower porosities.

\subsection{D bioprinting}

Current designs and fabrication methods fail to control the material's resorption properties and lack predefined internal geometry. Most scaffolds produced these days are randomly porous with no defined internal architecture which hinders vascular ingrowth, subsequently resulting in poor osseo-integration within the construct. Also in vivo experiments to investigate the influence of this internal geometry on cellular behaviour are therefore limited. This is mainly because the scaffold architecture produced by conventional strategies such as porogen leaching, gas foaming, freeze drying and melt molding is often process driven, rather than design driven. Advanced rapid prototyping has developed a whole array of approaches such as 3D bioprinting which creates arbitrary shaped, customised scaffolds with pre-defined internal architecture using the solid freeform approach that might help to overcome the above-mentioned drawbacks [123].

Bioprinting is regarded as the future technique for combining biomaterials, cells and to some extent also supporting components into 3D biological constructs to reconstruct deficient tissues or to model tissues and organs in a healthy and diseased state. The goal is to plan the precise positions of cells with computer aided design and then print them individually or layer-by-layer. Bioprinting is a relatively new method and mostly uses biocompatible hydrogels as they allow cell encapsulation in a gelated, hydrated and mechanically supportive 3D environment [124]. Only a few studies have been conducted so far using SF 
as a material for bioprinting processes. Recently, an inkjet printing process was developed and used to fabricate cell hosting SF nests [125], where patterned SF nests measuring 70-100 $\mu \mathrm{m}$ in diameter and modified with anionic and cationic side chains acted as anchored nests for the incubation and proliferation of E.coli cells. Using 3D printing, material stiffness can be modified effectively by altering the $\beta$-sheet content which consequently affects material degradation. It was shown recently that direct write silkgelatin scaffolds (Figure 3A) processed by sonication, possessed higher $\beta$-sheet $(25.4 \%)$ content over cross-linked structures using tyrosinase enzyme (14.2\%) (Figure 3B) [126]. Subsequently, biological activity of the material was assessed by culturing human nasal inferior turbinate tissue-derived mesenchymal progenitor cells which demonstrated enhanced osteogenic differentiation only on sonicated scaffolds possessing higher $\beta$-sheet content (Figure 3C-E), whereas their tyrosinase cross-linked counterpart demonstrated chondrogenic differentiation as a result of the lower $\beta$-sheet content and consequently lower material stiffness. This study suggested a strong significance of controlling the structural parameters of SF scaffolds such as their secondary conformation and consequently matrix stiffness to direct the cell population towards a specific lineage.

With the recombinant spider silk protein eADF4(C16), which mimics the repetitive core sequence of dragline SF, 3D printing without crosslinking agents or thickeners was shown by pre-gelling the solution overnight at $37^{\circ} \mathrm{C}$ and $95 \%$ relative humidity. The adhesion of different cell types which were seeded after the printing process, was tested and revealed that osteoblasts showed a much better adhesion than fibroblasts, myoblasts, HeLa cells or keratinocytes [127]. Thus, in the future this recombinant spider silk protein could prove useful for 3D bioprinting of cells for bone TE.

\subsection{Silk fibroin composite scaffolds}

For bone TE applications, SF is often used in combination with other biomaterials which have been shown to be beneficial for bone regeneration such as calcium-phosphate based inorganic components or collagen which are both found in bone in vivo [128-130]. The signaling cascades in response to HA are not yet completely understood. So far it is known that, upon interaction with HA, MSCs trigger signaling cascades such as ERK/Sox9, BMP/Smad, Wnt, TGF- $\beta$, MAPK, and Notch signaling pathways [131]. 
Recently it was suggested that nano-HA induced osteogenic differentiation and inhibited adipogenic differentiation of seeded BMSCs via upregulation of IL-1 $\alpha$; an autocrine/paracrine soluble factor that promotes bone formation by regulating collagen and osteopontin synthesis [132]. HA can be incorporated into porous SF scaffolds by direct deposition using an alternate soaking process of $\mathrm{CaCl}_{2}$ and $\mathrm{Na}_{2} \mathrm{HPO}_{4}$, by mixing it with a porogen like $\mathrm{NaCl}$ or by mixing $\mathrm{HA}$ with the regenerated SF solution $[133,134]$. The osteoconductivity of the resulting composite materials leads to higher formation of tissue engineered bone as compared to unmodified SF scaffolds. This can be attributed to the osteoconductivity of HA as well as the presence of nucleation sites for new mineral. Nanohydroxyapatite (nanoHA) has also been incorporated into SF hydrogels using ethanol as gelling agent. The resulting SF/nanoHA hydrogels had a higher compression modulus as well as increased osteogenic potential and could serve as filling material for small bone defects [135]. The incorporation of HA, due to its osteoconductivity and scaffold reinforcing properties, has also found application in electrospinning [136-139]. NanoHA was surfacemodified by $\gamma$-glycidoxypropyltrimethoxysilane to prevent aggregation and mixed with aqueous SF solution, resulting in beadless nanofibers with peak strengths at a nanoHA content of 20 wt.\% [139]. Modification of electrospun mats with BMP-2 and/or nanoparticles of HA supported growth and osteogenic differentiation of hMSCs when cultured in osteogenic medium whereby the combination of BMP-2 and HA resulted in the highest calcium deposition [140]. Next to HA, different composites containing SF have been investigated and proven to be osteoconductive, including chitsosan and aloe vera $[137,141]$. An interesting biomaterial combination for bone regeneration and tissue engineering is SF and demineralized bone matrix (DBM) which mainly consist of collagen and BMP-2 and has been widely used for bone regeneration in clinical applications. DBM powder or particles are difficult to handle which impedes its clinical application and usually requires the use of a biocompatible, viscous carrier such as putty. Better handling can be achieved through the incorporation of DBM into 3D SF scaffolds which also promoted osteogenesis in rat BMSCs and showed increased toughness and strength, probably through the particle incorporation [142].

To meet the compressive properties of bone e.g. to function as direct load-bearing support, without adding a different biomaterial to SF, self-reinforced SF composites have been explored. SF microfibers as well as 16 
SF microparticles have been used to increase the mechanical strength and robustness of SF scaffolds [143-146]. SF scaffolds containing microparticles $(\sim 3 \mu \mathrm{m})$ had a compressive modulus of $2.82 \pm 0.40 \mathrm{MPa}$ and showed slower enzymatic degradation as well as increased surface roughness [144]. SF scaffolds with incorporated large $(400-600 \mu \mathrm{m})$ and medium $(150-200 \mu \mathrm{m})$ fibers even achieved compressive modulus values in the range of approximately $10 \mathrm{MPa}$ [145], which was comparable to the compressive modulus of cancellous bone ( 10 MPa) and about 10 times lower than cortical bone ( 100 MPa), thus forming the toughest silk-based regenerated material developed so far. It is argued that the scaffold's strength is a result of the fibers bonding to the matrix and transferring load during compression which decreases stress buildup. These incorporated fibers not only increased the rigidity but also the surface roughness of the scaffolds and enhanced the differentiation of hMSCs towards the osteogenic lineage.

\section{Interaction of osteoclasts with silk fibroin}

The use of SF based scaffolds for bone TE is strongly connected to showing that MSCs can differentiate along the osteogenic lineage on them and mineralize their ECM. However, for a functional tissueengineered system which is intended to serve as a human in vitro model for drug discovery or testing, not only bone forming cells have to be taken into account but also bone resorbing cells. Only a few publications have dealt with the interaction of osteoclasts and SF so far. With SF films it was demonstrated that vapor stabilized SF and methanol stabilized SF support the growth of murine osteoblasts and osteoclasts in both single and co-cultures (Figure 4) [147]. The study also showed that when monocytes were cultured as a single cell type, cells that were positive for the osteoclast marker tartrate resistant acid phosphatase (TRAP), formed aggregates. However, osteoclasts and osteoblasts cocultures formed a homogeneous layer with interspersed TRAP positive cells. This indicates that SF may be a favorable biomaterial to study the cell-cell communication of osteoclasts and osteoblasts. On the contrary, it was reported that SF hydrolysate inhibits RANKL-induced formation of TRAP in RAW 264.7 cells, which is a murine monocyte macrophage cell line, in a time and dose dependent manner. It is not clear to which extent SF lysate would be present during a cell culture of osteoclasts on SF scaffolds. 
However, SF lysate may be used as a natural compound to prevent bone loss by reducing osteoclastogenesis.

\section{In vivo bone regeneration with silk fibroin}

The ability of a biomaterial to perform specific functions in patients cannot be evaluated only with in vitro tests as it is difficult to extrapolate from the in vitro to the in vivo situation. Therefore, in bone TE, both biocompatibility and bone promoting activity of the orthopaedic material should be demonstrated in in vivo studies as well. To assess its bone regeneration capacity, SF has been tested as porous scaffold, electrospun material and hydrogel in different animal models comprising mainly mice, rats, rabbits and sheep with calvarial, mandibular or femoral defects.

Studies were conducted to explore differences between collagen and silk proteins in bone regeneration. The presence of GER peptide sequence (GFP*GERGVEGPP*GPA) present in collagen I which acts as essential recognition site for the binding of $\alpha 2 \beta 1$ integrin, important in mediating osteoblast differentiation, could not be identified on B. mori SF [148]. However, when directly compared in vivo, in terms of their efficacy in promoting guided bone regeneration, it was revealed that the absolute volume of new bone formation did not vary significantly in SF and commercial Bio-Gide ${ }^{\circledR}$ collagen membranes $(8.75$ \pm 0.80 and $8.47 \pm 0.75 \mathrm{~mm}^{3}$ respectively) after 8 weeks of implantation in critical size rat calvarial defects [149]. Moreover, the SF-derived membranes reduce the risk of transmitting infections, providing a viable alternative for facilitating bone regeneration.

Porous SF scaffolds exhibit architectures with hierarchical organization which is comparable to cortical and trabecular bones and can facilitate osteogenesis within the defect site. For instance, 3D electrospun SF scaffolds resembling ECM-like structure with high porosity and controlled pore sizes (200-400 nm) showed significantly higher bone coverage over commercial PLA scaffolds possessing comparable morphology [122]. After 7 weeks of implantation in a critical sized rat calvaria defect, mean normal bone area of $78.30 \%$ was attained in SF scaffolds as opposed to only $49.31 \%$ in 3D PLA scaffolds, marking the efficiency of electrospun SF scaffolds over commercial PLAs for the treatment of large bone defects. 
Another group prepared nanofibrous membranes of such electrospun SF and demonstrated excellent biocompatibility, with complete defect coverage after 8 weeks of in vivo implantation in rabbit calvarial defects [150]. Also recently prepared resorbable screws of SF targeted for maxillofacial regeneration promoted satisfactory bone remodeling in rat femoral defects 8 weeks post-implantation comparable to commercially available poly-lactic-co-glycolic acid fixation systems [151].

It was demonstrated that native B. mori SF scaffolds without any pre-seeded osteogenic cells, showed insufficient bone regenerative potential required for complete in vivo healing of large femoral defects in mice [152]. A similar outcome was observed when these scaffolds were pre-seeded with un-differentiated hMSCs and implanted. However, with pre-differentiated mesenchymal stem cells, a major portion of the defect was healed with newly deposited bone tissue. Therefore, a series of subsequent studies investigated the osteogenic potential of premineralized or apatite-coated SF scaffolds in the mandibular defects of rats [153] and canines [154]. Increased bone formation was observed in premineralized constructs over uncoated ones in all the studies. Another observation was that the addition of BMP-2; a growth factor which plays a significant role in promoting osteogenic mechanisms in skeletal development [155], either exogenously incorporated on the scaffold [156] or transduced in the pre-seeded osteogenic cells [153], further accelerated the amount of new bone formation and increased the bone mineral density of the implanted constructs. Karageorgiou and co-workers demonstrated the upregulation of the osteogenic marker genes cbfa-1, osteopontin and osteocalcin together with a considerably higher bone formation $\left(0.28 \pm 0.15 \mathrm{~mm}^{2}\right.$ vs. $\left.0.12 \pm 0.05 \mathrm{~mm}^{2}\right)$ on SF scaffolds with incorporated BMP-2 and pre-seeded hMSCs as compared to only pre-seeded hMSCs without BMP-2, when implanted in mice calvarial defects [156]. Besides BMP-2, epigenetic modification of osteogenic precursors with additional sequences such as PHF8, a major H4K20/H3K9 demethylase involved in craniofacial and bone development [157], and SATB2 (special AT-rich sequence-binding protein 2) modified induced pluripotent stem cells [158] on SF constructs have been shown to promote healing of critical size defects of mice calvariae.

Though pre-culturing of osteogenic cells on SF has demonstrated excellent osteoinductivity in vivo, the procedure might not be as suitable for clinical use. The isolation protocols for autologous cells are invasive with lengthy culture times, making it rather inconvenient for patients. Therefore to further 19 
accelerate bone-related outcomes with cell-free naive SF matrices, surface properties of SF matrices have been altered. For instance, rather than loading with pre-differentiated cells, rapid mineralization of scaffolds was induced by incorporation of mesoporous bioactive glass [159], known to accelerate apatite deposition in contact with fluids in situ [160]. When implanted in mouse calvarial defects in vivo, bioactive glass incorporated in SF scaffolds facilitated the mineralized tissue formation $\left(7 \mathrm{~mm}^{3}\right)$, compared to unmodified SF scaffold where only peripheral bone deposition occurred $\left(2.5 \mathrm{~mm}^{3}\right)$. A similar in vivo response of unmodified SF was observed by Meinel and co-workers when B. mori SF scaffolds were implanted in mice calvarium [161]. The enhanced osteo-regenerative ability of the bioactive glass/SF scaffolds is mainly attributed to the consistent release of silica from bioactive glasses which subsequently up-regulates the bone-related markers in osteoblasts [162]. Others included polyaspartic acid in SF scaffolds followed by controlled calcium phosphate deposition to develop pre-mineralized SF scaffolds, which resulted in increased expression of BMP-2 in seeded human bone stem cells in vitro [163]. However, when implanted in the mandibular defects of canine, polyaspartic acid/SF scaffolds formed nominal traces of bone deposition along the defect periphery, while substantial bone formation could only be achieved with the addition of pre-seeded autologous BMSCs [153].

Recent advancements in the bone regeneration field have highlighted the absence of the RGD peptide motif in mulberry B. mori silk, a cell adhesion ligand typically present in nonmulberry $A$. mylitta [GenBank: AY136274.1], as one of the probable reasons for the low bone promoting ability of B. mori SF. Cell-free A. mylitta derived 3D SF sponges implanted in premaxillary defects of rat model demonstrated considerably higher bone volume over empty control defects $\left(64.89 \pm 7.46 \mathrm{~mm}^{2}\right.$ vs. $\left.27.28 \% \pm 9.2 \% \mathrm{~mm}^{2}\right)$ after 6 weeks of implantation [164]. In agreement with the above argument, a recently conducted study compared the repair of critical size rat calvarial defect with A. mylitta and B. mori lyophilized scaffolds (Figure 5) [165]. The results provided evidence of progressive mineralization with bony union in $A$. mylitta implanted defects within 6 months, while the B. mori scaffolds only provided nominal traces of mineral deposition within the same time span. However, a shortcoming in the study was that B. mori scaffolds were fabricated by dissolving the cocoons while A. mylitta SF proteins were directly isolated from the gland due to the difficult dissolution of A. mylitta cocoons in common solvents [166]. The 20 
translation of A. mylitta scaffolds to clinical settings for bone regenerative procedures still remains a challenge due to limited pre-clinical trials and the debate about the existence of RGD motifs [166].

For facilitating a congruent bone ingrowth, vascularization of the construct seems to be a pre-requisite. The development of angiogenesis concomitantly with osteogenesis will not only aid in the provision of oxygen and nutrients for osteogenic and endothelial cells, but also contribute towards the survival and differentiation of their counterpart [167]. Sun and co-workers efficiently demonstrated the in vitro coexistence and extensive matrix formation by hMSCs and human microvascular endothelial cells on SF/HA direct write composites with controlled pore morphologies [168]. When SF scaffolds with pre-formed microcapillary-like networks developed in vitro by co-culturing human dermal microvascular endothelial cells (HDMECs) and human osteoblasts were implanted in the subcutaneous tissue of mice, an extensive infiltration of host capillaries, identified with histological evaluation and immunohistochemical staining with human-specific antibodies, were distinctively visible in the construct [169]. Significantly reduced capillary invasion from the host occurred in SF scaffolds when HDMECs alone were cultured (8.81 \pm 2.11 vessels $/ \mathrm{mm}^{2}$ ) which clearly suggested the synergistic relationship of osteoblasts with endothelial cells. Determining the underlying key signaling mechanisms that trigger such cross-talks between the two cell types can prove to be very crucial for the development of novel scaffold materials.

SF has largely been favored in in vivo bone regenerative studies and its immuno-inflammatory response after implantation has therefore been investigated as well. For instance, when RGD-decorated SF was implanted in mouse calvarial defects, new bone deposition was evident consisting of both mature lamellar and immature woven bone [108]. A moderate level of typical immuno-inflammatory cells including macrophages, giant cells and foreign cells (lymphocytes and neutrophil granulocytes) were interspersed with the fibrous tissue and new bone tissue was observed via histopathology. However, this moderate range of immune reaction juxtaposed with the SF material falls within the expected range for such a defect. A comparable level of immuno-inflammatory response was observed when A. mylitta SF scaffolds with natural RGD sequences were implanted within a similar rat calvarial model. Moderate levels of immune cells, typically macrophages and giant cells penetrated during the initial period, did not impede infiltration of osteogenic precursors and subsequently a mature lamellar bone was deposited within 6 
months [165]. This moderate immunogenicity attained in SF scaffolds has been attributed in vitro to the silk II conformation possessing a high $\beta$-sheet content in $3 \mathrm{D}$ scaffolds when compared to silk I conformation in 2D SF films, as well as differences in hydrophilicity-hydrophobicity, topographical features, matrix stiffness and exposed surface area [170].

\section{Drug delivery for osteogenesis}

Due to its slower degradation rate, SF has been shown to possess outstanding properties as a carrier for bioactive drug delivery in several therapeutic applications, especially bone regeneration [171-175]. In an attempt to mimic the physiological bone hierarchy, various morphologies of SF have been investigated for the delivery of bone specific growth factors (e.g. BMP-2, platelet-derived growth factor), genes and enzymes which include porous 3D scaffolds, planar films, SF particles and electrospun fibers, with electrospun fibers being considered the most superior as they allow the fabrication of SF into fibers in the range of several nanometers to micrometers [176-180]. SF has been widely used to evaluate its potential for the delivery of bioactive molecules, especially BMP-2, known to play a crucial role in promoting osteogenesis. The delivery of BMP-2 using SF has been extensively evaluated for the application in bone regeneration [155]. BMP-2-loaded SF particles have successfully induced the formation of ectopic bone formation in rats, with increase in bone density concomitant with the delivery rate of BMP-2. Moreover, BMP-2-loaded SF groups showed superior bone formation over BMP-2 alone. The reasons for the observed phenomenon could be many. Direct administration of growth factors without immobilization on a carrier would result in a shorter half-life of the growth factor, slower penetration into the tissue and rapid diffusion of the delivery molecule from the site [181]. Therefore, repeated administration would be needed to consistently maintain the required concentration of the growth factor over long periods of time, which would be clinically impractical and very expensive [181,182]. Moreover, higher concentrations of the drug than required could have deleterious effects on the target tissue as well as ectopic sites [172]. This underlines the indispensable role of SF as an efficient carrier in increasing the efficacy of BMP-2 as a drug delivery molecule to promote bone regeneration. A BMP-2 delivery system composed of electrospun 
polycaprolactone nanofiber mesh tubes with the central hollow chamber injected with a SF hydrogel, was developed and tested for the treatment of an $8 \mathrm{~mm}$ critical size rat femoral segmental defect [183]. The results demonstrated effective bone formation in BMP-2 containing groups with biomechanical properties $(0.030 \pm 0.001 \mathrm{Nm} / \mathrm{deg}$ torsional stiffness and $0.31 \pm 0.02 \mathrm{Nm}$ maximum torque) comparable to native femurs and significant degradation of the SF hydrogels after 12 weeks of implantation. It was further demonstrated that the release of BMP-2 from SF scaffolds pre-seeded with hMSCs led to higher bone formation than with SF alone [156]. In this study, BMP-2 was adsorbed on the surface of SF scaffold by continuous immersion for $6 \mathrm{~h}$ in $0.05 \mathrm{mg} / \mathrm{ml}$ of BMP-2 solution. These BMP-2-adsorbed scaffolds were subsequently incubated in vitro in media and the release kinetics of the drug was quantified. Results revealed that $75 \%$ of BMP-2 was released into the media from the scaffold surface within the $1^{\text {st }}$ week of incubation followed by no release thereafter. Thus it may not be logical to define it as a sustained release method. Clearly, sustained release of BMP-2 from the carrier surface is an important aspect in bone TE and would benefit from a technique that can efficiently immobilize growth factors on the scaffold's surface in a way that leads to a sustained release of the molecule in situ. Another packaging strategy was to prepare SF particles with different sizes and components by a self-assembly procedure, resulting in complex calcium carbonate encrustation particles and functionalized with BMP-2 [178]. This process was used to regulate a sustained release of BMP-2 to the MSCs to trigger osteogenesis. The results showed higher ALP activity and expression of the osteogenesis-related genes Runx 2 and osteocalcin, which led to enhanced differentiation of MSCs along the osteogenic lineage. The combination of BMP-2 with calcium components in the SF/calcium carbonate particles specifically induced higher osteogenesis by synchronized activity. This was evident from the comparatively reduced osteogenic ability of control groups carrying BMP-2 carriers under similar conditions.

In another study, BMP-2 was immobilized on SF planar films by utilizing carbodiimide chemistry [177]. When hMSCs were cultured on these BMP-2 decorated films in the presence of osteogenic stimulants, enhanced differentiation towards the osteogenic lineage was evident by the significantly upregulated ALP activity, increased calcium deposition, and higher expression of collagen I, bone sialoprotein, osteopontin, osteocalcin, BMP-2, and cbfa1 genes. On the contrary, nominal traces of osteogenic differentiation could 23 
be identified on unmodified SF films cultured in osteogenic stimulants. The phenomenal tendency of osteogenesis exhibited by hMSCs on BMP-2 loaded SF was primarily a function of the immobilized protein and not the soluble BMP-2 in media as demonstrated by cell culture inserts.

To promote successful bone regeneration, efficient vascularization is a pre-requisite. Therefore, besides BMP-2, the angiogenic growth factor VEGF and its controlled delivery play a vital part in bone regeneration. It has been reported that sustained delivery of VEGF could aid in bone regeneration by promoting neovascularization and osteoblast differentiation [184]. Farokhi and co-workers fabricated electrospun poly(lactic-co-glycolic acid) nanofibers on the surface of freeze-dried SF/calcium phosphate substrates loaded with VEGF [176]. The controlled release profile of VEGF measured in vitro over a 28day period, classified the setup as a sustained delivery system with $83 \%$ sustained bioactivity post-release. The delivery system demonstrated good cytocompatibility in vitro, characterized by improved cell adhesion, proliferation and ALP activity of human osteoblast cells. In vivo, the induced neo-bone formation resulted in coverage of 8-mm critical size calvarial defects of rabbits. As VEGF and BMP-2 are important factors involved in angiogenesis and osteogenesis, Zhang et al. evaluated the potential of sonication-induced SF hydrogels as a carrier to encapsulate dual factors and test their efficacy in the repair of rabbit maxillary sinus floor augmentation [93]. In vivo, while BMP-2 alone mediated great bone formation and VEGF triggered neo- vascularization, cumulatively they promoted both osteogenesis and angiogenesis 12 weeks post-surgery.

\section{Conclusion and outlook}

$\mathrm{SF}$ is a natural biomaterial with unique biomedical and mechanical properties which make it favorable for a wide range of bone TE applications. It can be combined with several other biomaterials such as HA to create composite scaffolds which mimic the natural bone environment and increase the scaffold's osteogenic potential. Being a protein with tunable degradation and diverse modification options, SF possesses exceptional properties as a carrier for drugs and their sustained release in therapeutic applications. SF can be processed into different scaffolds such as injectable and printable gels, porous 
sponges and electrospun $2 \mathrm{D}$ and $3 \mathrm{D}$ constructs. With novel processing techniques it can be expected that new SF based scaffolds will be developed in the future and open up even more possibilities for bone TE applications. Clinical practice shows that most fractures will heal naturally and do not require TE strategies. Complex or non-union fractures might be more relevant for bone TE with SF. Creating solid organs and achieve reasonable tissue dimensions is a goal we are still far away from. However, these constructs will have to have a structure and SF with its versatile scaffold types offers a broad toolbox to choose from. In vivo studies using SF scaffolds for bone TE applications have proven the material's osteogenic potential. Nevertheless, these studies were done mostly in small animals that do not sufficiently predict their performance in humans. More research will have to be done before SF can be used for clinical trials and commercialized for bone TE applications. It is likely that SF will contribute to creating sophisticated bone tissue models to study ECM mineralization, mineral resorption and vascularization as well as to investigate bone diseases and possible therapeutic drugs. Most of the in vitro studies have focused on MSCs alone, their osteogenic differentiation and ability to mineralize their ECM. A better understanding is needed regarding 3D co-culture systems to create dynamic tissues which are able to remodel similar to bone. However, the future of SF in bone TE, where mechanically stable and long-term degradable biomaterials are needed, is promising and has great potential to bring viable strategies and innovations.

\section{Acknowledgements}

The research leading to these results has received funding from the European Union's Seventh Framework

Programme (FP/2007-2013) under Grant Agreement No. 336043 and funding from the Department of Biotechnology, India (BT/PR8038/MED/32/303/2013). 


\section{References}

[1] Griffith LG, Swartz MA. Capturing complex 3D tissue physiology in vitro. Nat Rev Mol Cell Biol 2006;7:211-24.

[2] Elliott NT, Yuan F. A review of three-dimensional in vitro tissue models for drug discovery and transport studies. J Pharm Sci 2011;100:59-74. doi:10.1002/jps.22257.

[3] Bose S, Roy M, Bandyopadhyay A. Recent advances in bone tissue engineering scaffolds. Trends Biotechnol 2012;30:546-54. doi:10.1016/j.tibtech.2012.07.005.

[4] Wu S, Liu X, Yeung KWK, Liu C, Yang X. Biomimetic porous scaffolds for bone tissue engineering. Mater Sci Eng R Reports 2014;80:1-36. doi:10.1016/j.mser.2014.04.001.

[5] Kasoju N, Bora U. Silk fibroin in tissue engineering. Adv Healthc Mater 2012;1:393-412. doi:10.1002/adhm.201200097.

[6] Buckwalter JA, Glimcher MJ, Cooper RR, Recker R. Bone biology. I: Structure, blood supply, cells, matrix, and mineralization. Instr Course Lect 1996;45:371-86.

[7] Roach HI. Why does bone matrix contain non-collagenous proteins? The possible roles of osteocalcin, osteonectin, osteopontin and bone sialoprotein in bone mineralisation and resorption. Cell Biol Int 1994;18:617-28. doi:http://dx.doi.org/10.1006/cbir.1994.1088.

[8] Olszta MJ, Cheng X, Jee SS, Kumar R, Kim Y-Y, Kaufman MJ, et al. Bone structure and formation: A new perspective. Mater Sci Eng R-REPORTS 2007;58:77-116. doi:10.1016/j.mser.2007.05.001.

[9] Watt FM, Hogan BLM. Out of Eden: Stem cells and their niches. Science (80- ) 2000;287:142730. doi:10.1126/science.287.5457.1427.

[10] Engler AJ, Sen S, Sweeney HL, Discher DE. Matrix Elasticity Directs Stem Cell Lineage Specification. Cell 2006;126:677-89. doi:http://dx.doi.org/10.1016/j.cell.2006.06.044.

[11] Watt FM, Huck WTS. Role of the extracellular matrix in regulating stem cell fate. Nat Rev Mol CELL Biol 2013;14:467-73. doi:10.1038/nrm3620.

[12] Taichman RS. Blood and bone: two tissues whose fates are intertwined to create the hematopoietic stem-cell niche. Blood 2004;105:2631-9.

[13] Techawiboonwong A, Song HK, Leonard MB, Wehrli FW. Cortical Bone Water: In Vivo Quantification with Ultrashort Echo-Time MR Imaging. Radiol Radiol 248705 2008;248:824-33. doi:10.1148/radiol.2482071995.

[14] Frantz C, Stewart KM, Weaver VM. The extracellular matrix at a glance. J Cell Sci 2010;123:4195-200. doi:10.1242/jcs.023820.

[15] Ehrlich P, Lanyon L. Mechanical strain and bone cell function: a review. Osteoporos Int 2002:688-700. 
[16] Suda T, Takahashi N, Udagawa N, Jimi E, Gillespie MT, Martin TJ. Modulation of osteoclast differentiation. Endocr Rev 1992;13:66-80. doi:10.1210/er.13.1.66.

[17] Väänänen HK, Zhao H, Mulari M, Halleen JM. The cell biology of osteoclast function. J Cell Sci 2000;113 ( Pt 3:377-81.

[18] Hsieh Y-F, Silva MJ. In vivo fatigue loading of the rat ulna induces both bone formation and resorption and leads to time-related changes in bone mechanical properties and density. J Orthop Res 2002;20:764-71. doi:10.1016/S0736-0266(01)00161-9.

[19] Boyce BF, Yao Z, Xing L. Osteoclasts have Multiple Roles in Bone in Addition to Bone Resorption. Crit Rev Eukaryot Gene Expr 2009;19:171-80.

[20] Khosla S. Minireview: The OPG/RANKL/RANK System. Endocrinology 2001;142:5050-5. doi:10.1210/endo.142.12.8536.

[21] Robling AG, Castillo AB, Turner CH. Biomechanical and molecular regulation of bone remodeling. Annu Rev Biomed Eng 2006;8:455-98. doi:10.1146/annurev.bioeng.8.061505.095721.

[22] Franz-Odendaal TA, Hall BK, Witten PE. Buried alive: How osteoblasts become osteocytes. Dev Dyn 2006;235:176-90. doi:10.1002/dvdy.20603.

[23] Dallas SL, Bonewald LF. Dynamics of the Transition from Osteoblast to Osteocyte. Ann N Y Acad Sci 2010;1192:437-43. doi:10.1111/j.1749-6632.2009.05246.x.

[24] Lanyon LE. Osteocytes, strain detection, bone modeling and remodeling. Calcif Tissue Int 1993;53 Suppl 1:S102-6; discussion S106-7.

[25] Burger EH, Klein-Nulend J. Mechanotransduction in bone--role of the lacuno-canalicular network. FASEB J 1999;13 Suppl:S101-12.

[26] Santos A, Bakker AD, Willems HME, Bravenboer N, Bronckers ALJJ, Klein-Nulend J. Mechanical loading stimulates BMP7, but not BMP2, production by osteocytes. Calcif Tissue Int 2011;89:318-26. doi:10.1007/s00223-011-9521-1.

[27] Bonewald L, Johnson M. Osteocytes, mechanosensing and Wnt signaling. Bone 2008;42:606-15.

[28] Klein-Nulend J, Semeins CM, Ajubi NE, Nijweide PJ, Burger EH. Pulsating fluid flow increases nitric oxide (NO) synthesis by osteocytes but not periosteal fibroblasts--correlation with prostaglandin upregulation. Biochem Biophys Res Commun 1995;217:640-8.

[29] Santos A, Bakker AD, Zandieh-Doulabi B, Semeins CM, Klein-Nulend J. Pulsating fluid flow modulates gene expression of proteins involved in Wnt signaling pathways in osteocytes. J Orthop Res 2009;27:1280-7. doi:10.1002/jor.20888.

[30] Robling AG, Niziolek PJ, Baldridge L a, Condon KW, Allen MR, Alam I, et al. Mechanical stimulation of bone in vivo reduces osteocyte expression of Sost/sclerostin. J Biol Chem 2008;283:5866-75. doi:10.1074/jbc.M705092200. 
[31] Klein-Nulend J, Bacabac RG, Bakker a D. Mechanical loading and how it affects bone cells: the role of the osteocyte cytoskeleton in maintaining our skeleton. Eur Cell Mater 2012;24:278-91.

[32] Pittenger MF, Mackay AM, Beck SC, Jaiswal RK, Douglas R, Mosca JD, et al. Multilineage potential of adult human mesenchymal stem cells. Science (80- ) 1999;284:143-7.

doi:10.1126/science.284.5411.143.

[33] Wang X, Wang Y, Gou W, Lu Q, Peng J, Lu S. Role of mesenchymal stem cells in bone regeneration and fracture repair: a review. Int Orthop 2013;37:2491-8. doi:10.1007/s00264-0132059-2.

[34] Hass R, Kasper C, Böhm S, Jacobs R. Different populations and sources of human mesenchymal stem cells (MSC): A comparison of adult and neonatal tissue-derived MSC. Cell Commun Signal 2011;9:12. doi:10.1186/1478-811X-9-12.

[35] Wagner W, Horn P, Castoldi M, Diehlmann A, Bork S, Saffrich R, et al. Replicative senescence of mesenchymal stem cells: a continuous and organized process. PLoS One 2008;3:e2213.

doi:10.1371/journal.pone.0002213.

[36] Ghibaudo M, Saez A, Trichet L, Xayaphoummine A, Browaeys J, Silberzan P, et al. Traction forces and rigidity sensing regulate cell functions. Soft Matter 2008;4:1836-43. doi:10.1039/B804103B.

[37] McMurray RJ, Wann AKT, Thompson CL, Connelly JT, Knight MM. Surface topography regulates wnt signaling through control of primary cilia structure in mesenchymal stem cells. Sci Rep 2013;3.

[38] Dalby MJ, Gadegaard N, Tare R, Andar A, Riehle MO, Herzyk P, et al. The control of human mesenchymal cell differentiation using nanoscale symmetry and disorder. Nat Mater 2007;6:9971003.

[39] Liu L, Ratner BD, Sage EH, Jiang S. Endothelial Cell Migration on Surface-Density Gradients of Fibronectin, VEGF, or Both Proteins. Langmuir 2007;23:11168-73. doi:10.1021/la701435x.

[40] Won Y-W, Patel AN, Bull DA. Cell surface engineering to enhance mesenchymal stem cell migration toward an SDF-1 gradient. Biomaterials 2014;35:5627-35.

doi:http://dx.doi.org/10.1016/j.biomaterials.2014.03.070.

[41] Yavari SA, van der Stok J, Chai YC, Wauthle R, Birgani ZT, Habibovic P, et al. Bone regeneration performance of surface-treated porous titanium. Biomaterials 2014;35:6172-81. doi:http://dx.doi.org/10.1016/j.biomaterials.2014.04.054.

[42] Unadkat H V, Hulsman M, Cornelissen K, Papenburg BJ, Truckenmüller RK, Carpenter AE, et al. An algorithm-based topographical biomaterials library to instruct cell fate. Proc Natl Acad Sci U S A 2011;108:16565-70. doi:10.1073/pnas.1109861108.

[43] Sutherland TD, Young JH, Weisman S, Hayashi CY, Merritt DJ. Insect Silk: One Name, Many Materials. Annu Rev Entomol 2010;55:171-88. doi:10.1146/annurev-ento-112408-085401. 
[44] Mhuka V, Dube S, Nindi MM. Chemical, structural and thermal properties of Gonometa postica silk fibroin, a potential biomaterial. Int J Biol Macromol 2013;52:305-11. doi:10.1016/j.ijbiomac.2012.09.010.

[45] Teulé F, Miao Y-G, Sohn B-H, Kim Y-S, Hull JJ, Fraser MJ, et al. Silkworms transformed with chimeric silkworm/spider silk genes spin composite silk fibers with improved mechanical properties. Proc Natl Acad Sci 2012;109 :923-8. doi:10.1073/pnas.1109420109.

[46] Zaoming W, Codina R, Fernandez-Caldas E, Lockey RF, Bukanz SC. Partial characterization of the silk allergens in mulberry silk extract. J Allergy Clin Immunol 2015;97:210. doi:10.1016/S0091-6749(96)80327-7.

[47] Soong HK, Kenyon KR. Adverse reactions to virgin silk sutures in cataract surgery. Ophthalmology 1984;91:479-83.

[48] Wen CM, Ye ST, Zhou LX, Yu Y. Silk-induced asthma in children: a report of 64 cases. Ann Allergy 1990;65:375-8.

[49] Hollander DH. Interstitial cystitis and silk allergy. Med Hypotheses 1994;43:155-6. doi:http://dx.doi.org/10.1016/0306-9877(94)90142-2.

[50] Chirila T V, Suzuki S, Bray LJ, Barnett NL, Harkin DG, Chirila T V, et al. Evaluation of silk sericin as a biomaterial : in vitro growth of human corneal limbal epithelial cells on Bombyx mori sericin membranes. Prog Biomater 2013;2:10. doi:10.1186/2194-0517-2-14.

[51] Aramwit P, Kanokpanont S, De-Eknamkul W, Srichana T. Monitoring of inflammatory mediators induced by silk sericin. J Biosci Bioeng 2009;107:556-61.

doi:http://dx.doi.org/10.1016/j.jbiosc.2008.12.012.

[52] Inoue S, Tanaka K, Arisaka F, Kimura S, Ohtomo K, Mizuno S. Silk Fibroin of Bombyx mori Is Secreted, Assembling a High Molecular Mass Elementary Unit Consisting of H-chain, L-chain, and P25, with a 6:6:1 Molar Ratio. J Biol Chem 2000;275 :40517-28. doi:10.1074/jbc.M006897200.

[53] Tanaka K, Inoue S, Mizuno S. Hydrophobic interaction of P25, containing Asn-linked oligosaccharide chains, with the H-L complex of silk fibroin produced by Bombyx mori. Insect Biochem Mol Biol 1999;29:269-76. doi:10.1016/S0965-1748(98)00135-0.

[54] Zhou C-Z, Confalonieri F, Jacquet M, Perasso R, Li Z-G, Janin J. Silk fibroin: Structural implications of a remarkable amino acid sequence. Proteins Struct Funct Bioinforma 2001;44:11922. doi:10.1002/prot.1078.

[55] Hayashi CY, Shipley NH, Lewis R V. Hypotheses that correlate the sequence, structure, and mechanical properties of spider silk proteins. Int J Biol Macromol 1999;24:271-5. doi:http://dx.doi.org/10.1016/S0141-8130(98)00089-0.

[56] Huemmerich D, Slotta U, Scheibel T. Processing and modification of films made from recombinant spider silk proteins. Appl Phys A Mater Sci Process 2006;82:219-22. doi:10.1007/s00339-005-3428-5. 
[57] Keten S, Xu Z, Ihle B, Buehler MJ. Nanoconfinement controls stiffness, strength and mechanical toughness of $\beta$-sheet crystals in silk. Nat Mater 2010;9:359-67.

[58] Hedhammar M, Rising A, Grip S, Martinez AS, Nordling K, Casals C, et al. Structural Properties of Recombinant Nonrepetitive and Repetitive Parts of Major Ampullate Spidroin 1 from Euprosthenops australis: Implications for Fiber Formation $\dagger$. Biochemistry 2008;47:3407-17. doi:10.1021/bi702432y.

[59] Sponner A, Vater W, Monajembashi S, Unger E, Grosse F, Weisshart K. Composition and Hierarchical Organisation of a Spider Silk. PLoS One 2007;2:e998. doi:10.1371/journal.pone.0000998.

[60] Gosline JM, Guerette PA, Ortlepp CS, Savage KN. The mechanical design of spider silks: from fibroin sequence to mechanical function. J Exp Biol 1999;202:3295-303.

[61] Pérez-Rigueiro J, Elices M, Llorca J, Viney C. Tensile properties of silkworm silk obtained by forced silking. J Appl Polym Sci 2001;82:1928-35. doi:10.1002/app.2038.

[62] Pérez-Rigueiro J, Elices M, Llorca J, Viney C. Effect of degumming on the tensile properties of silkworm (Bombyx mori) silk fiber. J Appl Polym Sci 2002;84:1431-7. doi:10.1002/app.10366.

[63] Cao Y, Wang B. Biodegradation of Silk Biomaterials. Int J Mol Sci 2009;10:1514-24. doi:10.3390/ijms 10041514.

[64] Minoura N, AIBA SI, Higuchi M, Gotoh Y, Tsukada M, Imai Y. Attachment and growth of fibroblast cells on silk fibroin. Biochem Biophys Res Commun 1995;208:511-6.

doi:10.1006/bbrc.1995.1368.

[65] Santin M, Motta A, Freddi G, Cannas M. In vitro evaluation of the inflammatory potential of the silk fibroin. J Biomed Mater Res 1999;46:382-9. doi:10.1002/(SICI)10974636(19990905)46:3<382::AID-JBM11>3.0.CO;2-R.

[66] Sakabe H, Ito H, Miyamoto T, Noishiki Y, Ha WS. In vivo blood compatibility of regenerated silk fibroin. Sen’i Gakkaishi 1989;45:487-90. doi:10.2115/fiber.45.11_487.

[67] Meinel L, Hofmann S, Karageorgiou V, Kirker-Head C, McCool J, Gronowicz G, et al. The inflammatory responses to silk films in vitro and in vivo. Biomaterials 2005;26:147-55. doi:10.1016/j.biomaterials.2004.02.047.

[68] Padol AR, Jayakumar K, Shridhar NB, Narayana Swamy HD, Narayana Swamy M, Mohan K. Safety Evaluation of Silk Protein Film (A Novel Wound Healing Agent) in Terms of Acute Dermal Toxicity, Acute Dermal Irritation and Skin Sensitization. Toxicol Int 2011;18:17-21. doi:10.4103/0971-6580.75847.

[69] Wharram SE, Zhang X, Kaplan DL, McCarthy SP. Electrospun Silk Material Systems for Wound Healing. Macromol Biosci 2010;10:246-57. doi:10.1002/mabi.200900274.

[70] Li M, Ogiso M, Minoura N. Enzymatic degradation behavior of porous silk fibroin sheets. Biomaterials 2003;24:357-65. doi:http://dx.doi.org/10.1016/S0142-9612(02)00326-5. 
[71] Horan RL, Antle K, Collette AL, Wang Y, Huang J, Moreau JE, et al. In vitro degradation of silk fibroin. Biomaterials 2005;26:3385-93. doi:10.1016/j.biomaterials.2004.09.020.

[72] Numata K, Cebe P, Kaplan DL. Mechanism of Enzymatic Degradation of Beta-sheet Crystals. Biomaterials 2010;31:2926. doi:10.1016/j.biomaterials.2009.12.026.

[73] Jin H-J, Park J, Karageorgiou V, Kim U-J, Valluzzi R, Cebe P, et al. Water-Stable Silk Films with Reduced $\beta$-Sheet Content. Adv Funct Mater 2005;15:1241-7. doi:10.1002/adfm.200400405.

[74] Lu Q, Hu X, Wang X, Kluge JA, Lu S, Cebe P, et al. Water-Insoluble Silk Films with Silk I Structure. Acta Biomater 2010;6:1380-7. doi:10.1016/j.actbio.2009.10.041.

[75] You R, Xu Y, Liu Y, Li X, Li M. Comparison of the in vitro and in vivo degradations of silk fibroin scaffolds from mulberry and nonmulberry silkworms. Biomed Mater 2015;10:15003.

[76] Huang G, Yang D, Sun C, Huang J, Chen K, Zhang C, et al. A quicker degradation rate is yielded by a novel kind of transgenic silk fibroin consisting of shortened silk fibroin heavy chains fused with matrix metalloproteinase cleavage sites. J Mater Sci Med 2014;25:1833-42. doi:10.1007/s10856-014-5220-6.

[77] Pritchard EM, Valentin T, Boison D, Kaplan DL. Incorporation of Proteinase Inhibitors into SilkBased Delivery Devices for Enhanced Control of Degradation and Drug Release. Biomaterials 2011;32:909-18. doi:10.1016/j.biomaterials.2010.09.055.

[78] Hutmacher DW. Scaffolds in tissue engineering bone and cartilage. Biomaterials 2000;21:2529_ 43.

[79] Zhang Y, Fan W, Ma Z, Wu C, Fang W, Liu G, et al. The effects of pore architecture in silk fibroin scaffolds on the growth and differentiation of mesenchymal stem cells expressing BMP7. Acta Biomater 2010;6:3021-8. doi:10.1016/j.actbio.2010.02.030.

[80] Murphy CM, Haugh MG, O’Brien FJ. The effect of mean pore size on cell attachment, proliferation and migration in collagen-glycosaminoglycan scaffolds for bone tissue engineering. Biomaterials 2010;31:461-6. doi:10.1016/j.biomaterials.2009.09.063.

[81] Joly P, Duda GN, Schöne M, Welzel PB, Freudenberg U, Werner C, et al. Geometry-driven cell organization determines tissue growths in scaffold pores: consequences for fibronectin organization. PLoS One 2013;8:e73545. doi:10.1371/journal.pone.0073545.

[82] Kim U-J, Park J, Li C, Jin H-J, Valluzzi R, Kaplan DL. Structure and properties of silk hydrogels. Biomacromolecules 2004;5:786-92. doi:10.1021/bm0345460.

[83] Yucel T, Cebe P, Kaplan DL. Vortex-Induced Injectable Silk Fibroin Hydrogels. Biophys J 2009;97:2044-50. doi:10.1016/j.bpj.2009.07.028.

[84] Wang X, Kluge JA, Leisk GG, Kaplan DL. Sonication-induced gelation of silk fibroin for cell encapsulation. Biomaterials 2008;29:1054-64. doi:10.1016/j.biomaterials.2007.11.003.

[85] Yucel T, Kojic N, Leisk GG, Lo TJ, Kaplan DL. Non-equilibrium Silk Fibroin Adhesives. J Struct Biol 2010;170:406-12. doi:10.1016/j.jsb.2009.12.012. 
[86] Bhardwaj N, Chakraborty S, Kundu SC. Freeze-gelled silk fibroin protein scaffolds for potential applications in soft tissue engineering. Int J Biol Macromol 2011;49:260-7. doi:10.1016/j.ijbiomac.2011.04.013.

[87] Matsumoto A, Chen J, Collette AL, Kim U-J, Altman GH, Cebe P, et al. Mechanisms of Silk Fibroin Sol-Gel Transitions. J Phys Chem B 2006;110:21630-8. doi:10.1021/jp056350v.

[88] Lu Q, Huang Y, Li M, Zuo B, Lu S, Wang J, et al. Silk Fibroin Electrogelation Mechanisms. Acta Biomater 2011;7:2394-400. doi:10.1016/j.actbio.2011.02.032.

[89] Samal SK, Kaplan DL, Chiellini E. Ultrasound Sonication Effects on Silk Fibroin Protein. Macromol Mater Eng 2013;298:1201-8. doi:10.1002/mame.201200377.

[90] Ak F, Oztoprak Z, Karakutuk I, Okay O. Macroporous Silk Fibroin Cryogels. Biomacromolecules 2013;14:719-27. doi:10.1021/bm3018033.

[91] Calabrese R, Kaplan DL. Silk ionomers for encapsulation and differentiation of human MSCs. Biomaterials 2012;33:7375-85. doi:10.1016/j.biomaterials.2012.06.043.

[92] Fini M, Motta A, Torricelli P, Glavaresi G, Aldini NN, Tschon M, et al. The healing of confined critical size cancellous defects in the presence of silk fibroin hydrogel. Biomaterials 2005;26:3527-36. doi:10.1016/j.biomaterials.2004.09.040.

[93] Zhang W, Wang X, Wang S, Zhao J, Xu L, Zhu C, et al. The use of injectable sonication-induced silk hydrogel for VEGF165 and BMP-2 delivery for elevation of the maxillary sinus floor. Biomaterials 2011;32:9415-24. doi:10.1016/j.biomaterials.2011.08.047.

[94] Pallotta I, Kluge JA, Moreau J, Calabrese R, Kaplan DL, Balduini A. Characteristics of platelet gels combined with silk. Biomaterials 2014;35:3678-87. doi:10.1016/j.biomaterials.2013.12.065.

[95] Aghaloo TL. b, Moy PK., Freymiller EG. Evaluation of Platelet-Rich Plasma in Combination with Anorganic Bovine Bone in the Rabbit Cranium: A Pilot Study. Int J Oral Maxillofac Implant 2004;19:59-65.

[96] Dallari D, Savarino L, Stagni C, Cenni E, Cenacchi A, Fornasari PM, et al. Enhanced Tibial Osteotomy Healing with Use of Bone Grafts Supplemented with Platelet Gel or Platelet Gel and Bone Marrow Stromal Cells. J Bone \&amp; Jt Surg 2007;89:2413-20.

[97] Kanthan SR, Kavitha G, Addi S, Choon DSK, Kamarul T. Platelet-rich plasma (PRP) enhances bone healing in non-united critical-sized defects: A preliminary study involving rabbit models. Injury 2011;42:782-9. doi:http://dx.doi.org/10.1016/j.injury.2011.01.015.

[98] Kasten P, Vogel J, Geiger F, Niemeyer P, Luginbühl R, Szalay K. The effect of platelet-rich plasma on healing in critical-size long-bone defects. Biomaterials 2008;29:3983-92. doi:http://dx.doi.org/10.1016/j.biomaterials.2008.06.014.

[99] Tamada Y. New Process to Form a Silk Fibroin Porous 3-D Structure. Biomacromolecules 2005;6:3100-6. doi:10.1021/bm050431f.

[100] Nazarov R, Jin H-J, Kaplan DL. Porous 3-D Scaffolds from Regenerated Silk Fibroin. Biomacromolecules 2004;5:718-26. doi:10.1021/bm034327e. 
[101] Wang Y, Rudym DD, Walsh A, Abrahamsen L, Kim H-J, Kim HS, et al. In vivo degradation of three-dimensional silk fibroin scaffolds. Biomaterials 2008;29:3415-28. doi:http://dx.doi.org/10.1016/j.biomaterials.2008.05.002.

[102] Correia C, Bhumiratana S, Yan L-P, Oliveira AL, Gimble JM, Rockwood D, et al. Development of silk-based scaffolds for tissue engineering of bone from human adipose-derived stem cells. Acta Biomater 2012;8:2483-92. doi:10.1016/j.actbio.2012.03.019.

[103] Oliveira AL, Sun L, Kim HJ, Hu X, Rice W, Kluge J, et al. Aligned silk-based 3-D architectures for contact guidance in tissue engineering. ACTA Biomater 2012;8:1530-42. doi:10.1016/j.actbio.2011.12.015.

[104] Kim HJ, Kim U-J, Vunjak-Novakovic G, Min B-H, Kaplan DL. Influence of macroporous protein scaffolds on bone tissue engineering from bone marrow stem cells. Biomaterials 2005;26:4442-52. doi:10.1016/j.biomaterials.2004.11.013.

[105] Uebersax L, Apfel T, Nuss KMR, Vogt R, Kim HY, Meinel L, et al. Biocompatibility and osteoconduction of macroporous silk fibroin implants in cortical defects in sheep. Eur J Pharm Biopharm 2013;85:107-18. doi:10.1016/j.ejpb.2013.05.008.

[106] Kim U-J, Park J, Kim HJ, Wada M, Kaplan DL. Three-dimensional aqueous-derived biomaterial scaffolds from silk fibroin. Biomaterials 2005;26:2775-85. doi:http://dx.doi.org/10.1016/j.biomaterials.2004.07.044.

[107] Sengupta S, Park S-H, Patel A, Carn J, Lee K, Kaplan DL. Hypoxia and Amino Acid Supplementation Synergistically Promote the Osteogenesis of Human Mesenchymal Stem Cells on Silk Protein Scaffolds. Tissue Eng Part A 2010;16:3623-34. doi:10.1089/ten.tea.2010.0302.

[108] Hofmann S, Hilbe M, Fajardo RJ, Hagenmüller H, Nuss K, Arras M, et al. Remodeling of tissueengineered bone structures in vivo. Eur J Pharm Biopharm 2013;85:119-29.

doi:10.1016/j.ejpb.2013.02.011.

[109] Thimm BW, Wüst S, Hofmann S, Hagenmüller H, Müller R. Initial cell pre-cultivation can maximize ECM mineralization by human mesenchymal stem cells on silk fibroin scaffolds. Acta Biomater 2011;7:2218-28. doi:10.1016/j.actbio.2011.02.004.

[110] Takeuchi A, Ohtsuki C, Miyazaki T, Tanaka H, Yamazaki M, Tanihara M. Deposition of bone-like apatite on silk fiber in a solution that mimics extracellular fluid. J Biomed Mater Res A 2003;65:283-9. doi:10.1002/jbm.a.10456.

[111] Lin F, Li Y, Jin J, Cai Y, Wei K, Yao J. Deposition behavior and properties of silk fibroin scaffolds soaked in simulated body fluid. Mater Chem Phys 2008;111:92-7. doi:10.1016/j.matchemphys.2008.03.019.

[112] Vetsch JR, Paulsen SJ, Müller R, Hofmann S. Effect of fetal bovine serum on mineralization in silk fibroin scaffolds. Acta Biomater 2015;13:277-85. doi:10.1016/j.actbio.2014.11.025.

[113] Marelli B, Ghezzi CE, Alessandrino A, Barralet JE, Freddi G, Nazhat SN. Silk fibroin derived polypeptide-induced biomineralization of collagen. Biomaterials 2012;33:102-8.

doi:10.1016/j.biomaterials.2011.09.039. 
[114] Jung S-R, Song N-J, Yang DK, Cho Y-J, Kim B-J, Hong J-W, et al. Silk proteins stimulate osteoblast differentiation by suppressing the Notch signaling pathway in mesenchymal stem cells. Nutr Res 2015;33:162-70. doi:10.1016/j.nutres.2012.11.006.

[115] Nagano A, Tanioka Y, Sakurai N, Sezutsu H, Kuboyama N, Kiba H, et al. Regeneration of the femoral epicondyle on calcium-binding silk scaffolds developed using transgenic silk fibroin produced by transgenic silkworm. Acta Biomater 2011;7:1192-201. doi:http://dx.doi.org/10.1016/j.actbio.2010.10.032.

[116] Hunter GK, Goldberg HA. Modulation of crystal formation by bone phosphoproteins: Role of glutamic acid-rich sequences in the nucleation of hydroxyapatite by bone sialoprotein. Biochem $\mathrm{J}$ 1994;302:175-9.

[117] Harris NL, Rattray KR, Tye CE, Underhill TM, Somerman MJ, D'Errico JA, et al. Functional analysis of bone sialoprotein: identification of the hydroxyapatite-nucleating and cell-binding domains by recombinant peptide expression and site-directed mutagenesis. Bone 2000;27:795802. doi:http://dx.doi.org/10.1016/S8756-3282(00)00392-6.

[118] Jin H-J, Fridrikh S V, Rutledge GC, Kaplan DL. Electrospinning Bombyx mori Silk with Poly(ethylene oxide). Biomacromolecules 2002;3:1233-9. doi:10.1021/bm025581u.

[119] Min B-M, Lee G, Kim SH, Nam YS, Lee TS, Park WH. Electrospinning of silk fibroin nanofibers and its effect on the adhesion and spreading of normal human keratinocytes and fibroblasts in vitro. Biomaterials 2004;25:1289-97. doi:http://dx.doi.org/10.1016/j.biomaterials.2003.08.045.

[120] Jin H-J, Chen J, Karageorgiou V, Altman GH, Kaplan DL. Human bone marrow stromal cell responses on electrospun silk fibroin mats. Biomaterials 2004;25:1039-47. doi:http://dx.doi.org/10.1016/S0142-9612(03)00609-4.

[121] Ki CS, Park SY, Kim HJ, Jung H-M, Woo KM, Lee JW, et al. Development of 3-D nanofibrous fibroin scaffold with high porosity by electrospinning: implications for bone regeneration. Biotechnol Lett 2008;30:405-10. doi:10.1007/s10529-007-9581-5.

[122] Park SY, Ki CS, Park YH, Jung HM, Woo KM, Kim HJ. Electrospun Silk Fibroin Scaffolds with Macropores for Bone Regeneration: An In Vitro and In Vivo Study. TISSUE Eng PART A 2010;16:1271-9. doi:10.1089/ten.tea.2009.0328.

[123] Ghosh S, Parker ST, Wang X, Kaplan DL, Lewis JA. Direct-Write Assembly of Microperiodic Silk Fibroin Scaffolds for Tissue Engineering Applications. Adv Funct Mater 2008;18:1883-9. doi:10.1002/adfm.200800040.

[124] Dababneh AB, Ozbolat IT. Bioprinting Technology: A Current State-of-the-Art Review. J Manuf Sci Eng 2014;136:61016.

[125] Suntivich R, Drachuk I, Calabrese R, Kaplan DL, Tsukruk V V. Inkjet Printing of Silk Nest Arrays for Cell Hosting. Biomacromolecules 2014;15:1428-35. doi:10.1021/bm500027c.

[126] Das S, Pati F, Choi Y, Rijal G, Shim J-H, Won S, et al. Bioprintable, cell-laden silk fibroin-gelatin hydrogel supporting multilineage differentiation of stem cells for fabrication of three-dimensional tissue constructs. Acta Biomater 2015;11:233-46. doi:http://dx.doi.org/10.1016/j.actbio.2014.09.023. 
[127] Schacht K, Jüngst T, Schweinlin M, Ewald A, Groll J, Scheibel T. Biofabrication of Cell-Loaded 3D Spider Silk Constructs. Angew Chemie Int Ed 2015;54:2816-20. doi:10.1002/anie.201409846.

[128] He P, Sahoo S, Ng KS, Chen K, Toh SL, Goh JCH. Enhanced osteoinductivity and osteoconductivity through hydroxyapatite coating of silk-based tissue-engineered ligament scaffold. J Biomed Mater Res A 2013;101:555-66. doi:10.1002/jbm.a.34333.

[129] Panda N, Biswas A, Pramanik K, Jonnalagadda S. Enhanced osteogenic potential of human mesenchymal stem cells on electrospun nanofibrous scaffolds prepared from eri-tasar silk fibroin. $\mathrm{J}$ Biomed Mater Res B Appl Biomater 2014;00B:1-12. doi:10.1002/jbm.b.33272.

[130] Zhang Y, Wu C, Friis T, Xiao Y. The osteogenic properties of CaP/silk composite scaffolds. Biomaterials 2010;31:2848-56. doi:10.1016/j.biomaterials.2009.12.049.

[131] Kim JSJ, Park S, Kang W, Jang HKHKJ. Signaling responses of osteoblast cells to hydroxyapatite : the activation of ERK and SOX9 2008;10:138-42. doi:10.1007/s00774-007-08046.

[132] Liu H, Wei G, Fei Y, Shi H, Xiong S, Wu Y, et al. Composite scaffolds of nano-hydroxyapatite and silk fi broin enhance mesenchymal stem cell-based bone regeneration via the interleukin 1 alpha autocrine / paracrine signaling loop. Biomaterials 2015;49:103-12. doi:10.1016/j.biomaterials.2015.01.017.

[133] Jiang J, Hao W, Li Y, Yao J, Shao Z, Li H, et al. Hydroxyapatite/regenerated silk fibroin scaffoldenhanced osteoinductivity and osteoconductivity of bone marrow-derived mesenchymal stromal cells. Biotechnol Lett 2013;35:657-61. doi:10.1007/s10529-012-1121-2.

[134] Bhumiratana S, Grayson WL, Castaneda A, Rockwood DN, Gil ES, Kaplan DL, et al. Nucleation and growth of mineralized bone matrix on silk-hydroxyapatite composite scaffolds. Biomaterials 2011;32:2812-20. doi:10.1016/j.biomaterials.2010.12.058.

[135] Ribeiro M, de Moraes MA, Beppu MM, Garcia MP, Fernandes MH, Monteiro FJ, et al. Development of silk fibroin/nanohydroxyapatite composite hydrogels for bone tissue engineering. Eur Polym J 2015;67:66-77. doi:http://dx.doi.org/10.1016/j.eurpolymj.2015.03.056.

[136] Panda N, Bissoyi A, Pramanik K, Biswas A. Directing osteogenesis of stem cells with hydroxyapatite precipitated electrospun eri-tasar silk fibroin nanofibrous scaffold. J Biomater Sci Ed 2014;25:1440-57. doi:10.1080/09205063.2014.943548.

[137] Suganya S, Venugopa I J, Ramakrishna S, Lakshmi BS, Dev VRG. Aloe Vera/Silk Fibroin/Hydroxyapatite Incorporated Electrospun Nanofibrous Scaffold for Enhanced Osteogenesis. J Biomater Tissue Eng 2014;4:9-19. doi:10.1166/jbt.2014.1139.

[138] Pascu EI, Stokes J, McGuinness GB. Electrospun composites of PHBV, silk fibroin and nanohydroxyapatite for bone tissue engineering. Mater Sci Eng C-MATERIALS Biol Appl 2013;33:4905-16. doi:10.1016/j.msec.2013.08.012.

[139] Kim H, Che L, Ha Y, Ryu W. Mechanically-reinforced electrospun composite silk fibroin nanofibers containing hydroxyapatite nanoparticles. Mater Sci Eng C-MATERIALS Biol Appl 2014;40:324-35. doi:10.1016/j.msec.2014.04.012. 
[140] Li C, Vepari C, Jin H-J, Kim HJ, Kaplan DL. Electrospun silk-BMP-2 scaffolds for bone tissue engineering. Biomaterials 2006;27:3115-24. doi:10.1016/j.biomaterials.2006.01.022.

[141] Chen J-P, Chen S-H, Lai G-J. Preparation and characterization of biomimetic silk fibroin/chitosan composite nanofibers by electrospinning for osteoblasts culture. NANOSCALE Res Lett 2012;7:111. doi:10.1186/1556-276X-7-170.

[142] Ding X, Wei X, Huang Y, Guan C, Zou T, Wang S, et al. Delivery of demineralized bone matrix powder using a salt-leached silk fibroin carrier for bone regeneration. J Mater Chem B 2015;3:3177-88. doi:10.1039/C5TB00046G.

[143] Rajkhowa R, Gil ES, Kluge J, Numata K, Wang L, Wang X, et al. Reinforcing Silk Scaffolds with Silk Particles. Macromol Biosci 2010;10:599-611. doi:10.1002/mabi.200900358.

[144] Gil ES, Kluge JA, Rockwood DN, Rajkhowa R, Wang L, Wang X, et al. Mechanical Improvements to Reinforced Porous Silk Scaffolds. J Biomed Mater Res A 2011;99:16-28. doi:10.1002/jbm.a.33158.

[145] Mandal BB, Grinberg A, Gil ES, Panilaitis B, Kaplan DL. High-strength silk protein scaffolds for bone repair. Proc Natl Acad Sci U S A 2012;109:7699-704. doi:10.1073/pnas.1119474109.

[146] Rockwood DN, Gil ES, Park S-H, Kluge JA, Grayson W, Bhumiratana S, et al. Ingrowth of human mesenchymal stem cells into porous silk particle reinforced silk composite scaffolds: An in vitro study. Acta Biomater 2011;7:144-51. doi:10.1016/j.actbio.2010.07.020.

[147] Jones GL, Motta A, Marshall MJ, Haj AJ El, Cartmell SH. Osteoblast: Osteoclast co-cultures on silk fibroin, chitosan and PLLA films. Biomaterials 2009;30:5376-84.

doi:http://dx.doi.org/10.1016/j.biomaterials.2009.07.028.

[148] Mizuno M, Fujisawa R, Kuboki Y. Type I collagen-induced osteoblastic differentiation of bonemarrow cells mediated by collagen- $\alpha 2 \beta 1$ integrin interaction. J Cell Physiol 2000;184:207-13. doi:10.1002/1097-4652(200008)184:2<207::AID-JCP8>3.0.CO;2-U.

[149] Kim J-Y, Yang B-E, Ahn J-H, Park SO, Shim H-W. Comparable efficacy of silk fibroin with the collagen membranes for guided bone regeneration in rat calvarial defects. J Adv Prosthodont 2014;6:539-46. doi:10.4047/jap.2014.6.6.539.

[150] Kim K-H, Jeong L, Park H-N, Shin S-Y, Park W-H, Lee S-C, et al. Biological efficacy of silk fibroin nanofiber membranes for guided bone regeneration. J Biotechnol 2005;120:327-39. doi:http://dx.doi.org/10.1016/j.jbiotec.2005.06.033.

[151] Perrone GS, Leisk GG, Lo TJ, Moreau JE, Haas DS, Papenburg BJ, et al. The use of silk-based devices for fracture fixation. Nat Commun 2014;5:3385. doi:10.1038/ncomms4385.

[152] Meinel L, Betz O, Fajardo R, Hofmann S, Nazarian A, Cory E, et al. Silk based biomaterials to heal critical sized femur defects. Bone 2006;39:922-31.

doi:http://dx.doi.org/10.1016/j.bone.2006.04.019.

[153] Jiang X, Zhao J, Wang S, Sun X, Zhang X, Chen J, et al. Mandibular repair in rats with premineralized silk scaffolds and BMP-2-modified bMSCs. Biomaterials 2009;30:4522-32. doi:http://dx.doi.org/10.1016/j.biomaterials.2009.05.021. 
[154] Zhao J, Zhang Z, Wang S, Sun X, Zhang X, Chen J, et al. Apatite-coated silk fibroin scaffolds to healing mandibular border defects in canines. Bone 2009;45:517-27. doi:http://dx.doi.org/10.1016/j.bone.2009.05.026.

[155] Wang RN, Green J, Wang Z, Deng Y, Qiao M, Peabody M, et al. Bone Morphogenetic Protein (BMP) signaling in development and human diseases. Genes Dis 2014;1:87-105. doi:http://dx.doi.org/10.1016/j.gendis.2014.07.005.

[156] Karageorgiou V, Tomkins M, Fajardo R, Meinel L, Snyder B, Wade K, et al. Porous silk fibroin 3$\mathrm{D}$ scaffolds for delivery of bone morphogenetic protein-2 in vitro and in vivo. J Biomed Mater Res Part A 2006;78A:324-34. doi:10.1002/jbm.a.30728.

[157] Han Q, Yang P, Wu Y, Meng S, Sui L, Zhang L, et al. Epigenetically Modified Bone Marrow Stromal Cells (BMSCs) in Silk Scaffolds Promote Craniofacial Bone Repair and Wound Healing. Tissue Eng Part A 2015. doi:10.1089/ten.TEA.2014.0484.

[158] Ye J-H, Xu Y-J, Gao J, Yan S-G, Zhao J, Tu Q, et al. Critical-size calvarial bone defects healing in a mouse model with silk scaffolds and SATB2-modified iPSCs. Biomaterials 2011;32:5065-76. doi:http://dx.doi.org/10.1016/j.biomaterials.2011.03.053.

[159] Wu C, Zhang Y, Zhou Y, Fan W, Xiao Y. A comparative study of mesoporous glass/silk and nonmesoporous glass/silk scaffolds: Physiochemistry and in vivo osteogenesis. Acta Biomater 2011;7:2229-36. doi:http://dx.doi.org/10.1016/j.actbio.2010.12.019.

[160] Midha S, Kim TB, van den Bergh W, Lee PD, Jones JR, Mitchell CA. Preconditioned 70S30C bioactive glass foams promote osteogenesis in vivo. Acta Biomater 2013;9:9169-82. doi:http://dx.doi.org/10.1016/j.actbio.2013.07.014.

[161] Meinel L, Fajardo R, Hofmann S, Langer R, Chen J, Snyder B, et al. Silk implants for the healing of critical size bone defects. Bone 2005;37:688-98. doi:10.1016/j.bone.2005.06.010.

[162] Xynos ID, Edgar AJ, Buttery LDK, Hench LL, Polak JM. Gene-expression profiling of human osteoblasts following treatment with the ionic products of Bioglass ${ }^{\circledR} 45 \mathrm{~S} 5$ dissolution. J Biomed Mater Res 2001;55:151-7. doi:10.1002/1097-4636(200105)55:2<151::AID-JBM1001>3.0.CO;2D.

[163] Kim HJ, Kim U-J, Kim HS, Li C, Wada M, Leisk GG, et al. Bone tissue engineering with premineralized silk scaffolds. Bone 2008;42:1226-34. doi:10.1016/j.bone.2008.02.007.

[164] Kim J-H, Moon H-J, Kim T-H, Jo J-M, Yang SH, Naskar D, et al. A novel in vivo platform for studying alveolar bone regeneration in rat. J Tissue Eng 2013;4. doi:10.1177/2041731413517705.

[165] Sahu N, Baligar P, Midha S, Kundu B, Bhattacharjee M, Mukherjee S, et al. Nonmulberry silk fibroin scaffold shows superior osteoconductivity than mulberry silk fibroin in calvarial bone regeneration. Adv Healthc Mater n.d.;Accepted.

[166] Silva SS, Popa EG, Gomes ME, Oliveira MB, Nayak S, Subia B, et al. Silk hydrogels from nonmulberry and mulberry silkworm cocoons processed with ionic liquids. Acta Biomater 2013;9:8972-82. doi:http://dx.doi.org/10.1016/j.actbio.2013.06.044. 
[167] Kanczler JM, Oreffo ROC. Osteogenesis and angiogenesis: the potential for engineering bone. Eur Cell Mater 2008;15:100-14.

[168] Sun L, Parker ST, Syoji D, Wang X, Lewis JA, Kaplan DL. Direct-Write Assembly of 3D Silk/Hydroxyapatite Scaffolds for Bone Co-Cultures. Adv Healthc Mater 2012;1:729-35. doi:10.1002/adhm.201200057.

[169] Unger RE, Ghanaati S, Orth C, Sartoris A, Barbeck M, Halstenberg S, et al. The rapid anastomosis between prevascularized networks on silk fibroin scaffolds generated in vitro with cocultures of human microvascular endothelial and osteoblast cells and the host vasculature. Biomaterials 2010;31:6959-67. doi:http://dx.doi.org/10.1016/j.biomaterials.2010.05.057.

[170] Bhattacharjee M, Schultz-Thater E, Trella E, Miot S, Das S, Loparic M, et al. The role of 3D structure and protein conformation on the innate and adaptive immune responses to silk-based biomaterials. Biomaterials 2013;34:8161-71. doi:http://dx.doi.org/10.1016/j.biomaterials.2013.07.018.

[171] Uebersax L, Merkle HP, Meinel L. Insulin-like growth factor I releasing silk fibroin scaffolds induce chondrogenic differentiation of human mesenchymal stem cells. J Control Release 2008;127:12-21. doi:http://dx.doi.org/10.1016/j.jconrel.2007.11.006.

[172] Wang X, Wenk E, Zhang X, Meinel L, Vunjak-Novakovic G, Kaplan DL. Growth factor gradients via microsphere delivery in biopolymer scaffolds for osteochondral tissue engineering. J Control Release 2009;134:81-90. doi:http://dx.doi.org/10.1016/j.jconrel.2008.10.021.

[173] Wang X, Zhang X, Castellot J, Herman I, Iafrati M, Kaplan DL. Controlled release from multilayer silk biomaterial coatings to modulate vascular cell responses. Biomaterials 2008;29:894-903. doi:http://dx.doi.org/10.1016/j.biomaterials.2007.10.055.

[174] Uebersax L, Mattotti M, Papaloïzos M, Merkle HP, Gander B, Meinel L. Silk fibroin matrices for the controlled release of nerve growth factor (NGF). Biomaterials 2007;28:4449-60. doi:http://dx.doi.org/10.1016/j.biomaterials.2007.06.034.

[175] Schneider A, Wang XY, Kaplan DL, Garlick JA, Egles C. Biofunctionalized electrospun silk mats as a topical bioactive dressing for accelerated wound healing. Acta Biomater 2009;5:2570-8. doi:10.1016/j.actbio.2008.12.013.

[176] Farokhi M, Mottaghitalab F, Shokrgozar MA, Ai J, Hadjati J, Azami M. Bio-hybrid silk fibroin/calcium phosphate/PLGA nanocomposite scaffold to control the delivery of vascular endothelial growth factor. Mater Sci Eng C 2014;35:401-10. doi:http://dx.doi.org/10.1016/j.msec.2013.11.023.

[177] Karageorgiou V, Meinel L, Hofmann S, Malhotra A, Volloch V, Kaplan D. Bone morphogenetic protein-2 decorated silk fibroin films induce osteogenic differentiation of human bone marrow stromal cells. J Biomed Mater Res A 2004;71:528-37. doi:10.1002/jbm.a.30186.

[178] Shi P, Abbah S a, Saran K, Zhang Y, Li J, Wong H-K, et al. Silk fibroin-based complex particles with bioactive encrustation for bone morphogenetic protein 2 delivery. Biomacromolecules 2013;14:4465-74. doi:10.1021/bm401381s. 
[179] Zhang Y-Q, Zhou W-L, Shen W-D, Chen Y-H, Zha X-M, Shirai K, et al. Synthesis, characterization and immunogenicity of silk fibroin-l-asparaginase bioconjugates. J Biotechnol 2005;120:315-26. doi:http://dx.doi.org/10.1016/j.jbiotec.2005.06.027.

[180] Haider M, Leung V, Ferrari F, Crissman J, Powell J, Cappello J, et al. Molecular Engineering of Silk-Elastinlike Polymers for Matrix-Mediated Gene Delivery: Biosynthesis and Characterization. Mol Pharm 2005;2:139-50. doi:10.1021/mp049906s.

[181] Chen B, Lin H, Wang J, Zhao Y, Wang B, Zhao W, et al. Homogeneous osteogenesis and bone regeneration by demineralized bone matrix loading with collagen-targeting bone morphogenetic protein-2. Biomaterials 2007;28:1027-35.

doi:http://dx.doi.org/10.1016/j.biomaterials.2006.10.013.

[182] Kolambkar YM, Dupont KM, Boerckel JD, Huebsch N, Mooney DJ, Hutmacher DW, et al. An Alginate-based Hybrid System for Growth Factor Delivery in the Functional Repair of Large Bone Defects. Biomaterials 2011;32:65-74. doi:10.1016/j.biomaterials.2010.08.074.

[183] Diab T, Pritchard EM, Uhrig BA, Boerckel JD, Kaplan DL, Guldberg RE. A silk hydrogel-based delivery system of bone morphogenetic protein for the treatment of large bone defects. J Mech Behav Biomed Mater 2012;11:123-31. doi:http://dx.doi.org/10.1016/j.jmbbm.2011.11.007.

[184] Kanczler JM, Ginty PJ, White L, Clarke NMP, Howdle SM, Shakesheff KM, et al. The effect of the delivery of vascular endothelial growth factor and bone morphogenic protein-2 to osteoprogenitor cell populations on bone formation. Biomaterials 2010;31:1242-50. doi:http://dx.doi.org/10.1016/j.biomaterials.2009.10.059. 


\section{Figure Captions}

Figure 1: Silk fibroin hydrogels (A) and cryogels (B) formed at 50 and $-18{ }^{\circ} \mathrm{C}$, respectively, undergoing a compression test $\mathrm{CSF}=4.2 \%, \mathrm{EGDE}=20 \mathrm{mmol} / \mathrm{g}, \mathrm{TEMED}=0.10 \%$. Adapted with permission [90]. Copyright 2013 American Chemical Society.

Figure 2: SEM images (A-C) of silk fibroin scaffolds decorated with RGD sequences with small (106$212 \mu \mathrm{m})$, medium $(212-300 \mu \mathrm{m})$ or large $(300-425 \mu \mathrm{m})$ pore diameters. Micro-CT images $(\mathrm{D}-\mathrm{L})$ taken from the same scaffolds seeded with hMSC after 5 weeks of cultivation under osteogenic conditions in spinner flasks, showing the constructs as seen from the top (D-F), from the side (G-I) and at higher magnification (J-L). Bar length: $500 \mu \mathrm{m}(\mathrm{A}-\mathrm{C}), 2 \mathrm{~mm}(\mathrm{D}-\mathrm{I}), 1 \mathrm{~mm}(\mathrm{~J}-\mathrm{L})$. Reprinted with permission [108]. Copyright 2013 Elsevier.

Figure 3: (A) Schematic showing 3D printed SF-gelatin constructs produced by direct writing. (B) Characterization of SF-gelatin ink demonstrating significantly increased $\beta$-sheet content in sonicated constructs over tyrosinase cross-linked constructs. (C) SEM image of custom-made 3D filamentous architecture and osteogenic differentiation of hMSC laden constructs confirmed by alizarin Red S (D) and ALP staining (E). Abbreviations - SF: silk fibroin, hMSC: human mesenchymal stem cells, SEM: scanning electron microscopy, ALP: alkaline phosphatase. Adapted with permission [126]. Copyright 2014 Elsevier

Figure 4: SEM images of single and co-cultures of osteoblasts (OB) and osteoclasts (OC) on silk fibroin (SF), chitosan and polylactic acid (PLLA) after 10 days of culture. (A) Vapor treated SF film with OB:OC, (B) vapor treated SF film with OC, (C) vapor treated SF film with OB, (D) methanol treated SF film with OB:OC, (E) methanol treated SF film with OC, (F) methanol treated SF film with OB. (G) chitosan film with OB:OC, (H) chitosan film with OC, (I) chitosan film with OB, (J) PLLA film with OB:OC and (K) PLLA film with OC, (L) PLLA film with OB, Scale bar $=75 \mu \mathrm{m}$. Reprinted with permission [147]. Copyright 2009 Elsevier. 
Figure 5: Bone regeneration in Antherea mylitta (Am) and Bombyx mori (Bm) scaffolds. (A) X-ray radiographs 6 months post-surgery showing defect coverage with neo bone formation in Am constructs (left panel) and no bone formation in Bm constructs (right panel). Centre image shows surgical site drilled with $5 \mathrm{~mm}$ bilateral calvarial defects. (B,C) Histological analysis of constructs 3 months post-surgery stained with H\&E (B) and Alizarin Red S (C) showing moderate immuno-inflammatory responses with enhanced bone deposition in Am (arrows) (left panel). In Bm constructs, profuse infiltration of immunoinflammatory cells is conspicuous with minimal traces of bone matrix deposition (right panel). M: Month. Adapted with permission [165]. Copyright Wiley 2015. 


\section{Table Captions}

Table 1: Silk fibroin (SF) scaffold processing techniques for bone tissue engineering applications.

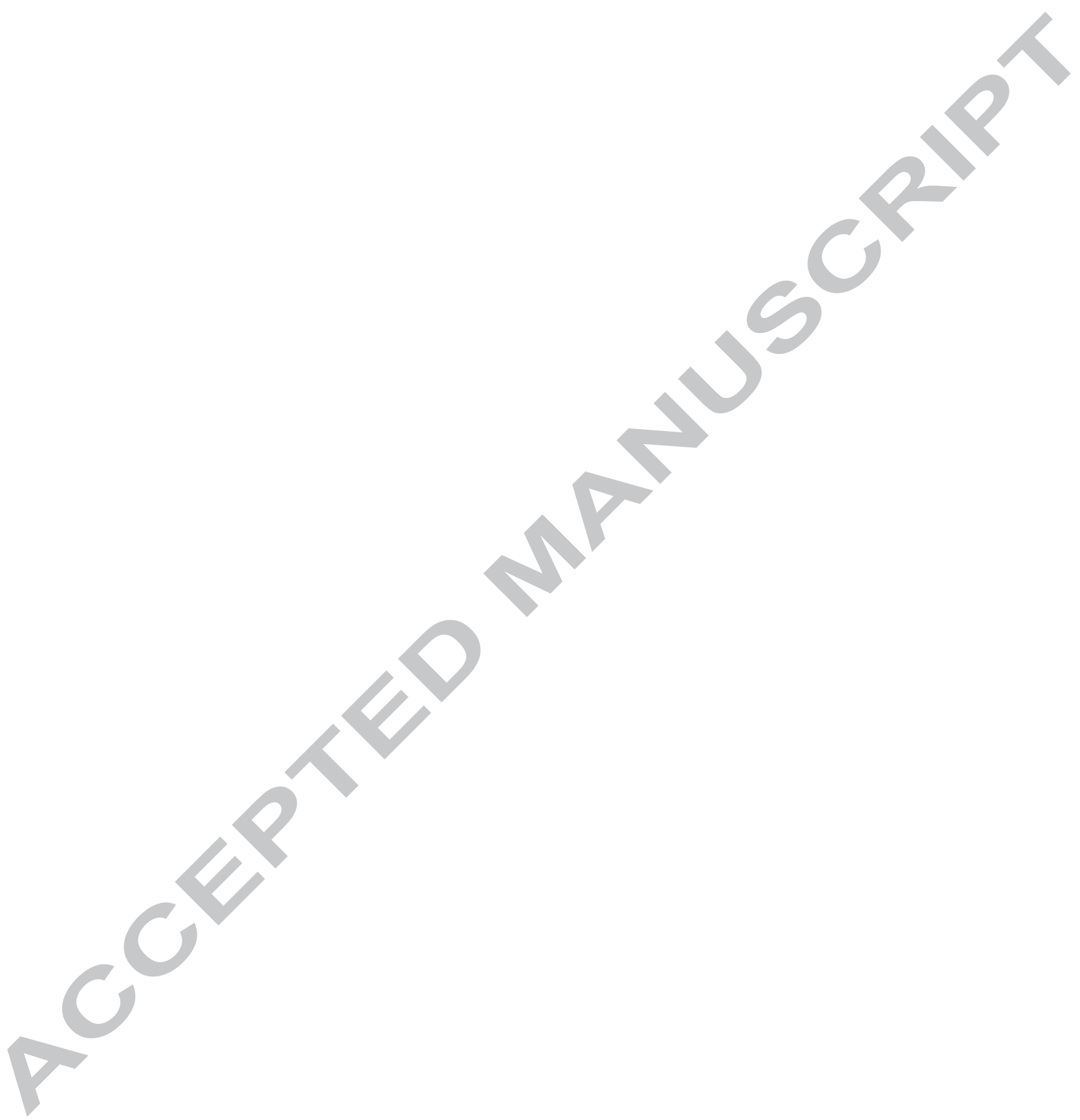


Figure 1

\section{ACCEPTED MANUSCRIPT}

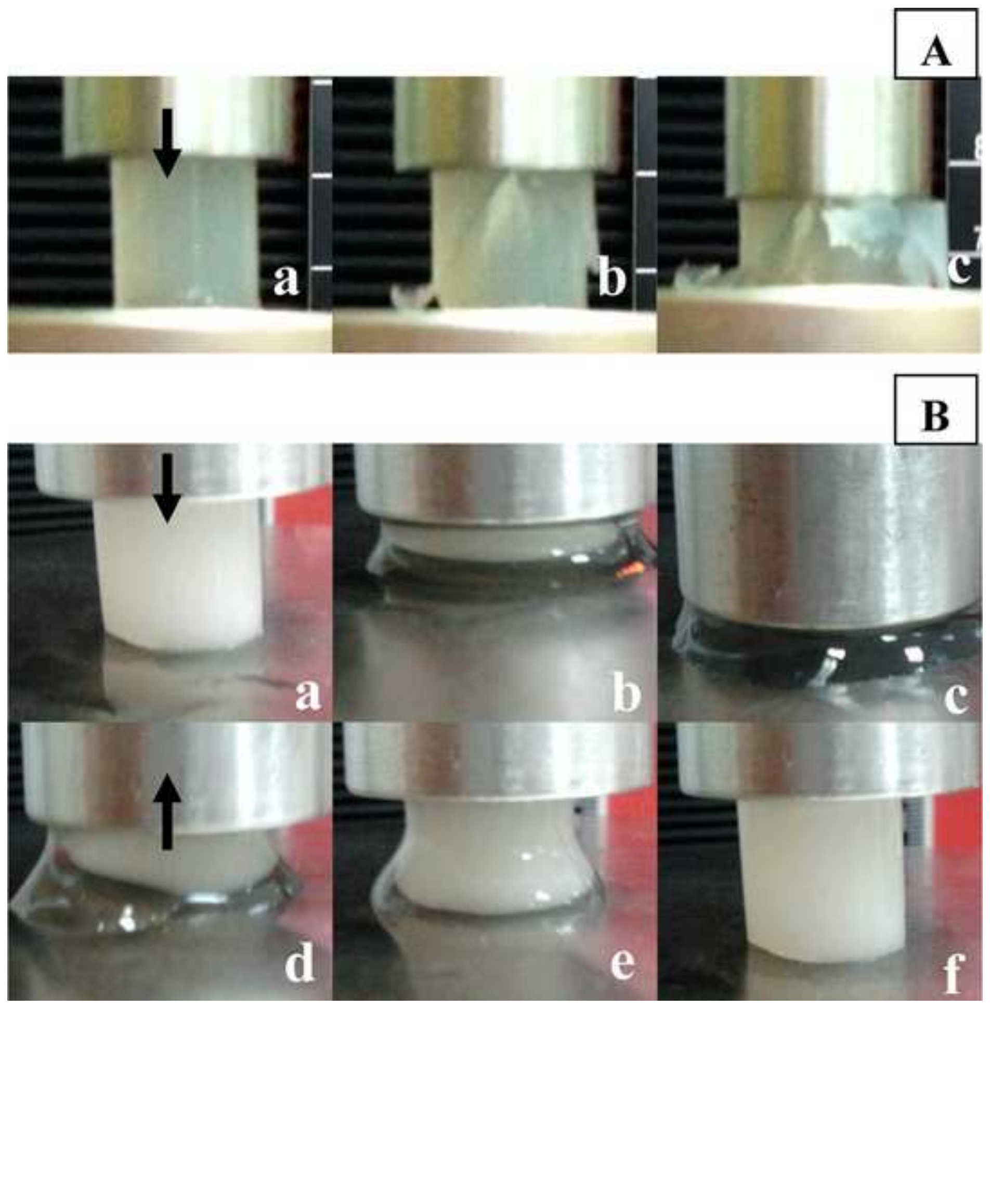

A

$-$

e

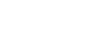
b-

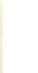

B 


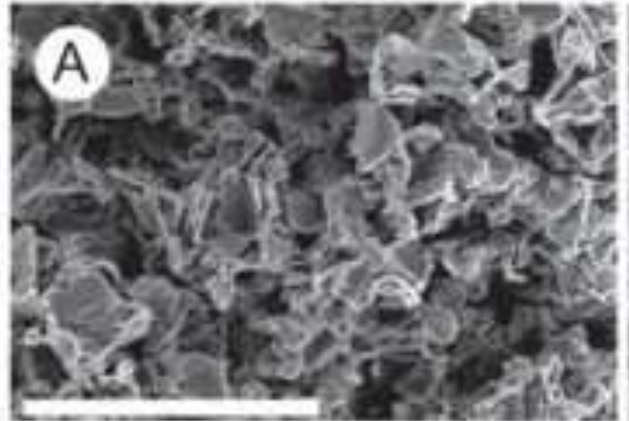

\section{(D)}

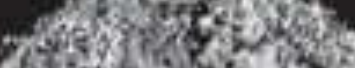

abing

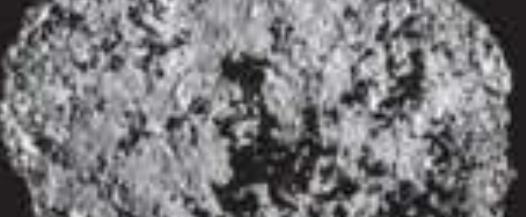

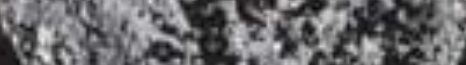

solvoging

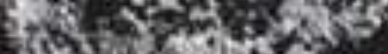

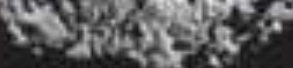

달

G

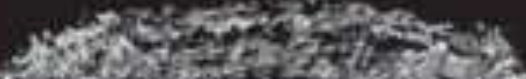

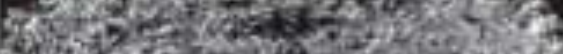

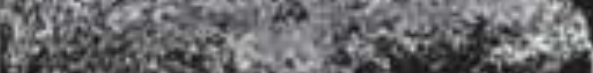

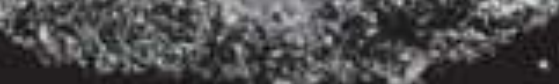

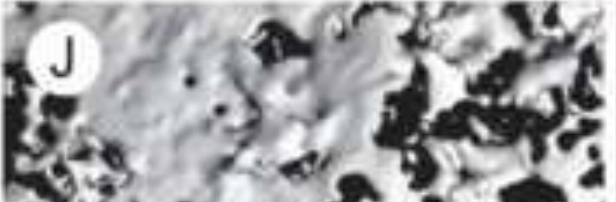

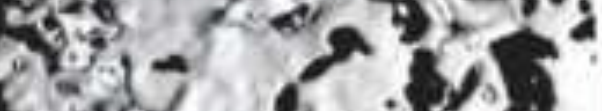

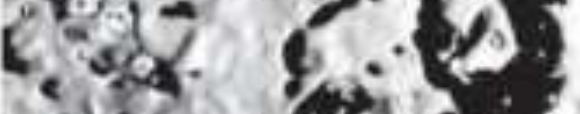

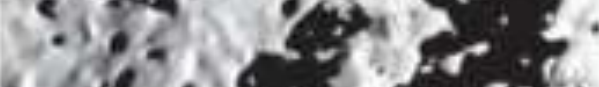

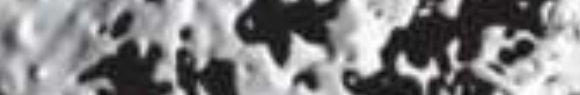
Q

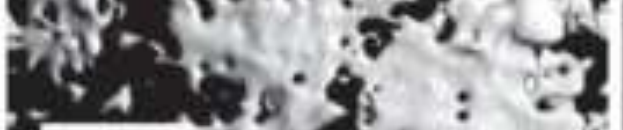
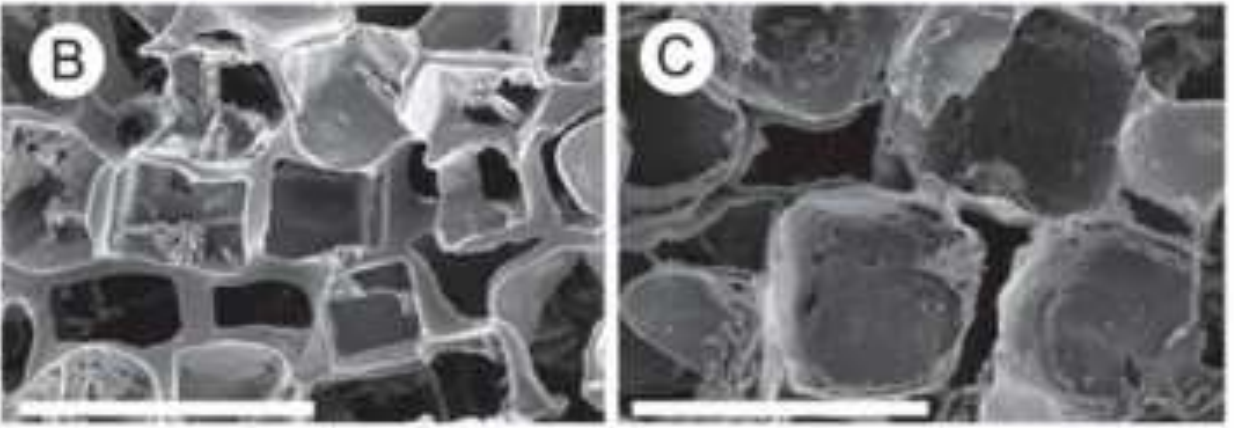

(E)

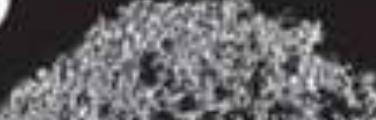

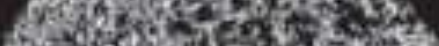

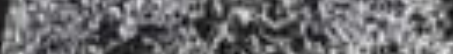

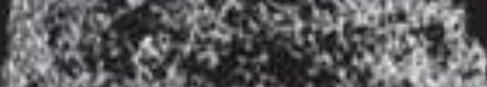

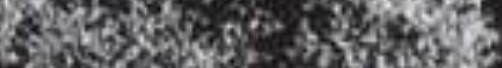

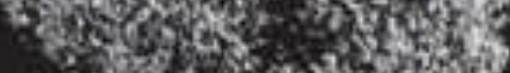

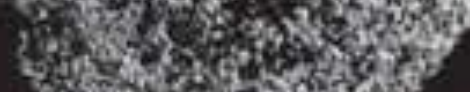

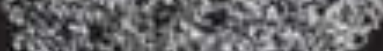

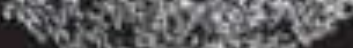
reaste

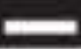

(H)

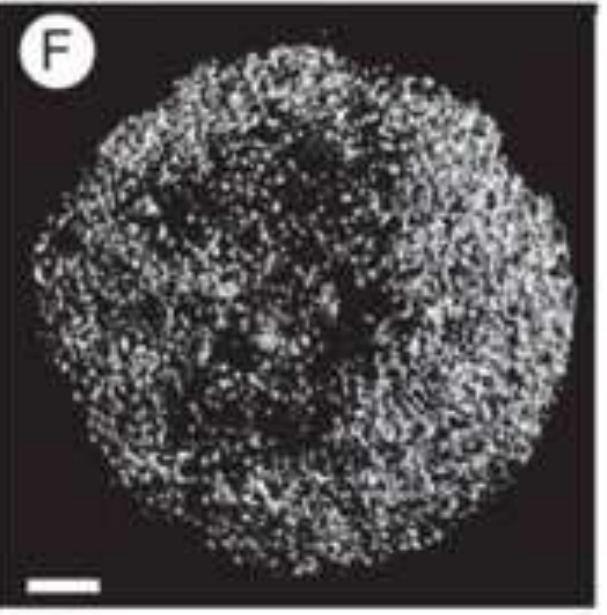

(1)

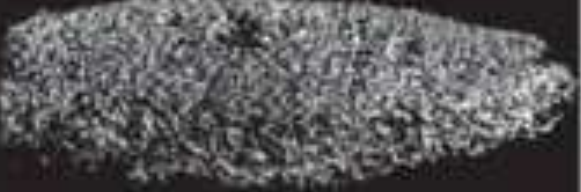

workas

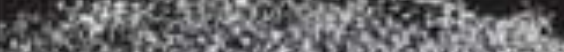

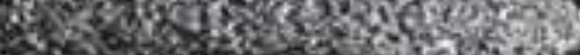

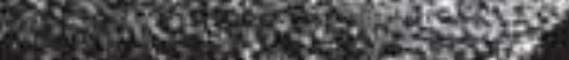

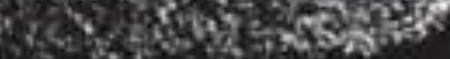

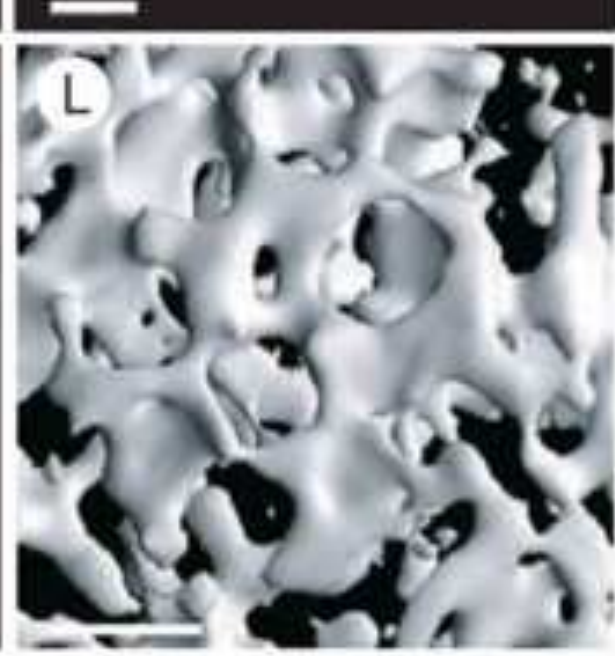


A
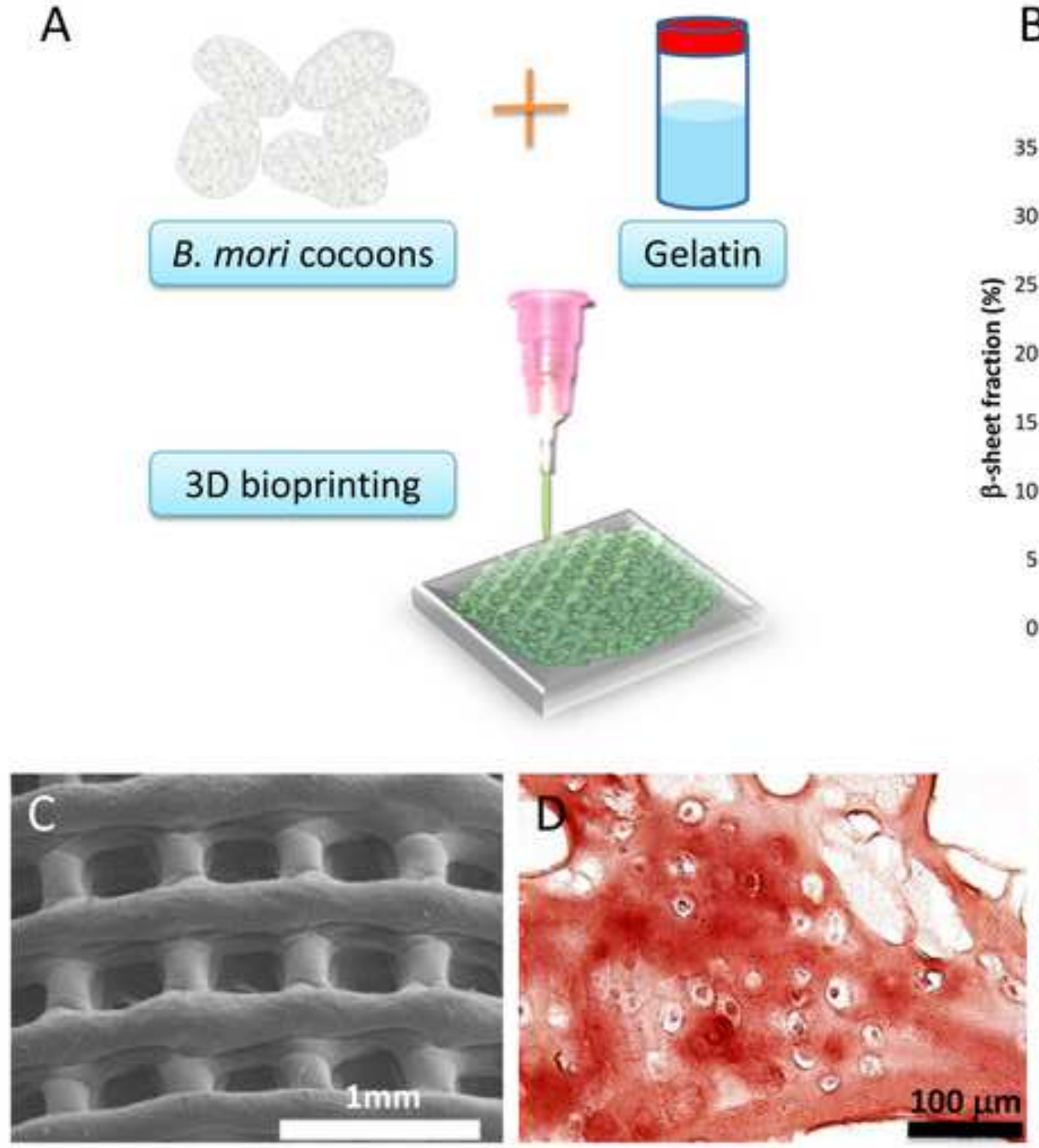

B
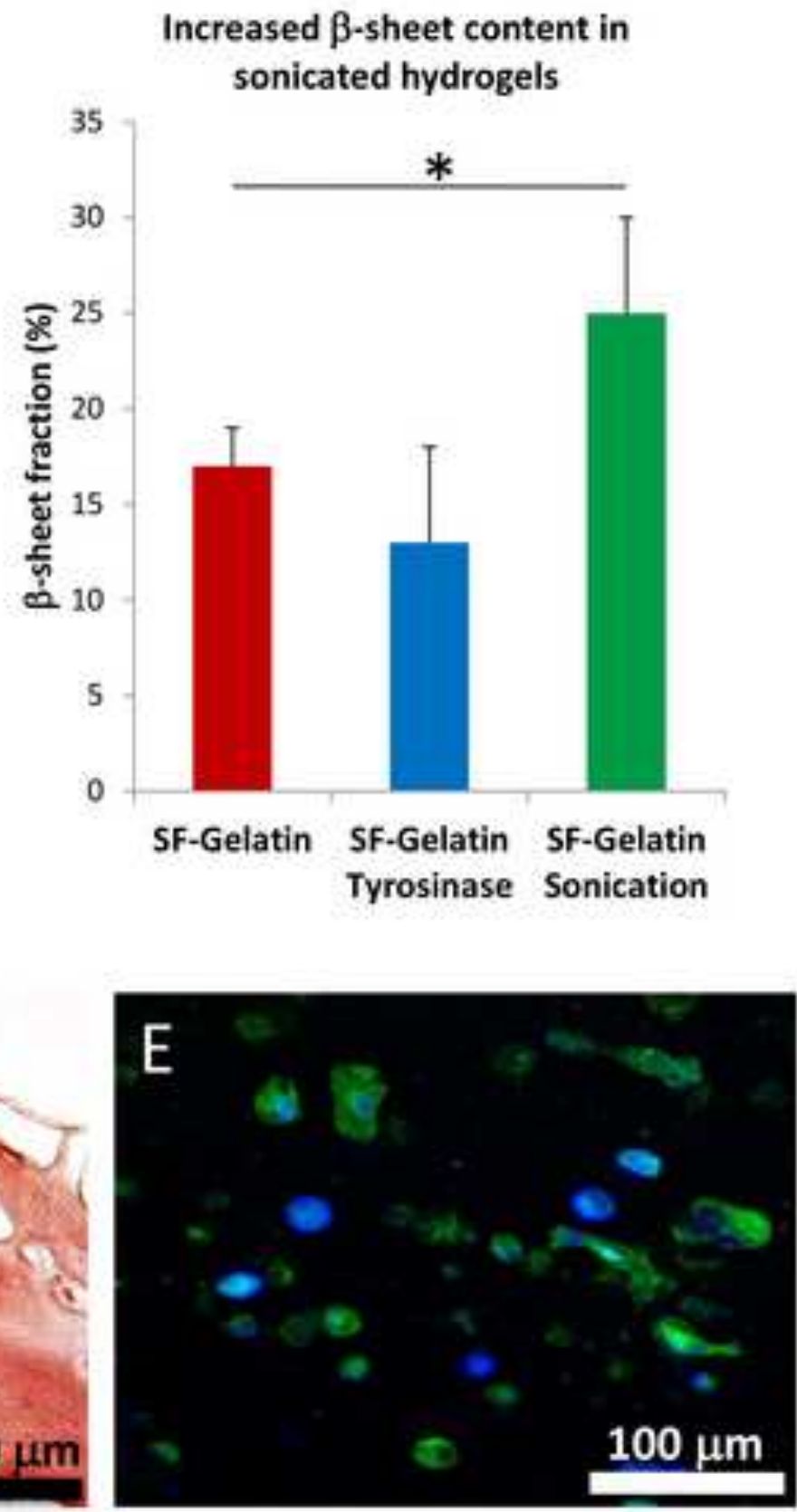

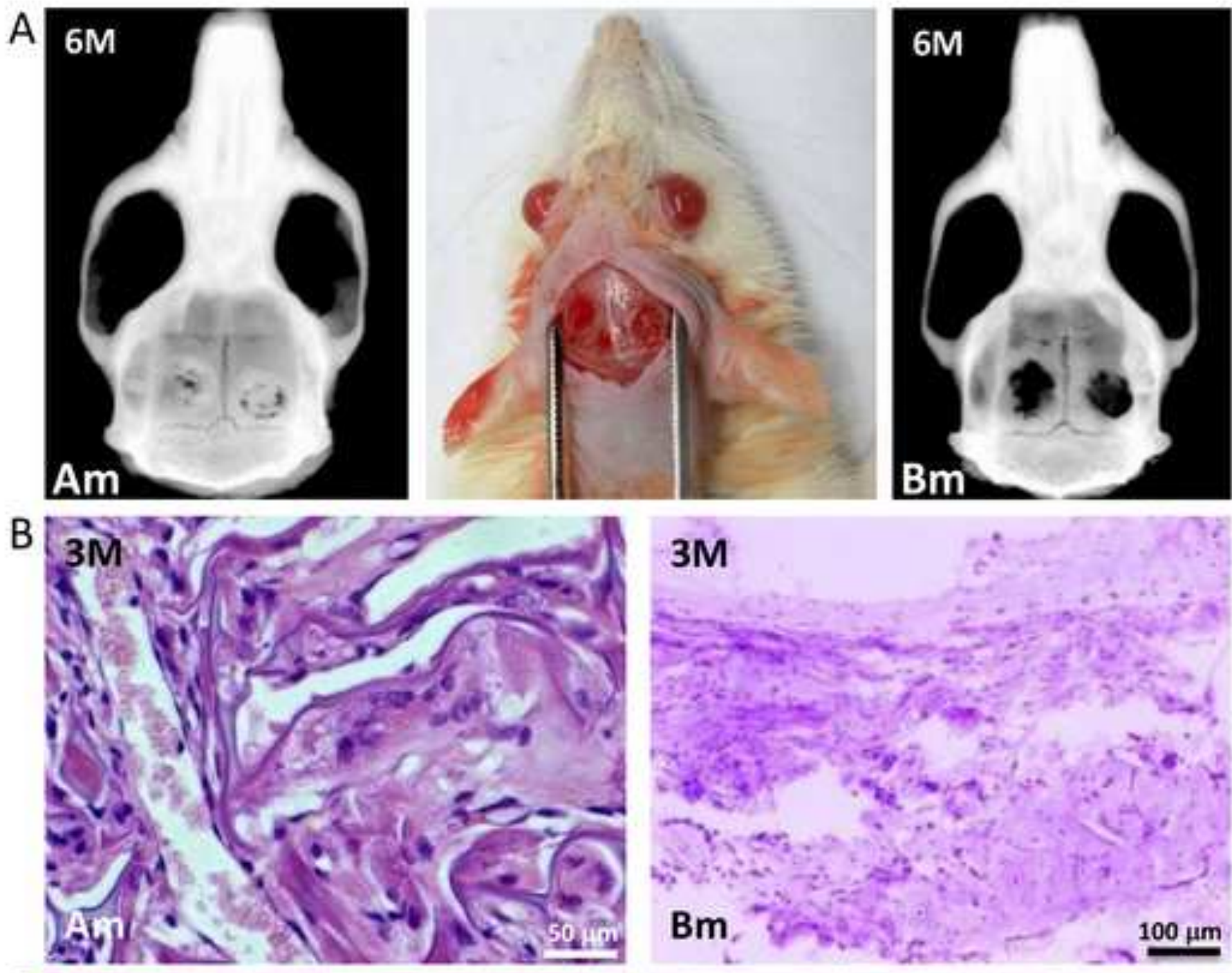

C 3 M
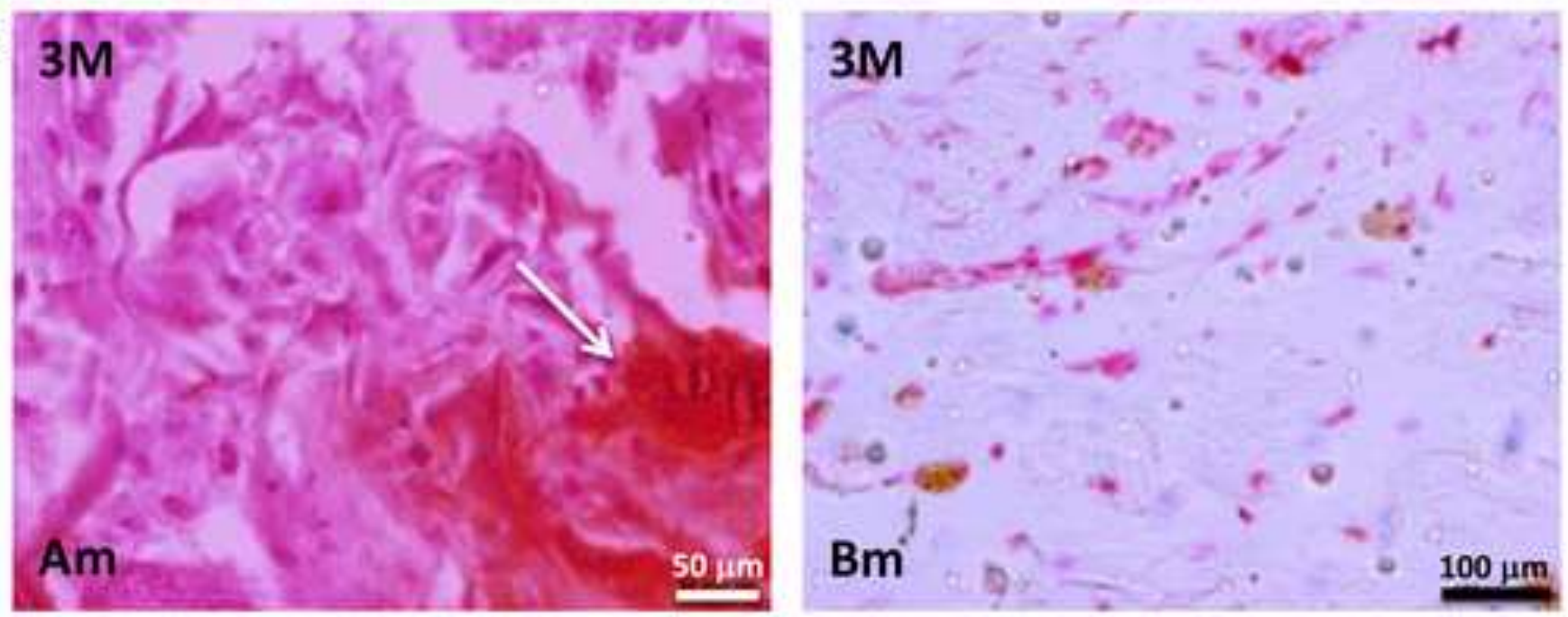


\begin{tabular}{|c|c|c|c|c|c|}
\hline Format & Fabrication technique & Description & Advantages & Disadvantages & References \\
\hline \multirow[t]{2}{*}{ Hydrogels } & $\begin{array}{l}\text { High temperatures, low } \mathrm{pH} \text {, high } \\
\text { ionic strength, vortexing, sonication, } \\
\text { freeze gelation }\end{array}$ & $\begin{array}{l}\text { Structural changes of the SF in an aqueous } \\
\text { solution occur from a disordered state to a } \beta \text { - } \\
\text { sheet conformation which physically cross- } \\
\text { links and stabilizes the gel }\end{array}$ & $\begin{array}{l}\text { Injectable for in vivo } \\
\text { applications, cells } \\
\text { can be encapsulated }\end{array}$ & Small pore sizes & [82-87] \\
\hline & Electrogelation & $\begin{array}{l}\text { An electric fields induces assembly of SF } \\
\text { nanoparticles into larger nano- or } \\
\text { microspheres which leads to random } \\
\text { structures and } \alpha \text {-helices }\end{array}$ & $\begin{array}{l}\text { Temperature } \\
\text { reversible, gelation } \\
\text { of low concentrated } \\
\text { solutions }(1 \%), \\
\text { injectable }\end{array}$ & $\begin{array}{l}\text { Electrical impulse might be } \\
\text { unsuitable for cell encapsulation, } \\
\text { small pore size }\end{array}$ & {$[88]$} \\
\hline \multirow[t]{2}{*}{ Sponges } & Freeze drying & $\begin{array}{l}\text { Ice crystals formed within the aqueous SF } \\
\text { solution through freezing are removed } \\
\text { through ice sublimation which induces } \\
\text { porosity }\end{array}$ & $\begin{array}{l}\text { Good porosity and } \\
\text { interconnectivity, } \\
\text { also lamellar } \\
\text { structures are } \\
\text { possible }\end{array}$ & Pore size is limited & {$[99,100,103]$} \\
\hline & Porogen leaching & $\begin{array}{l}\text { A SF solution is poured over } \\
\text { porogens and solidified; then the porogen is } \\
\text { leached out }\end{array}$ & $\begin{array}{l}\text { Simple, adaptable, } \\
\text { easily controllable } \\
\text { pore size and } \\
\text { geometry }\end{array}$ & $\begin{array}{l}\text { Difficult to design precise pore } \\
\text { orientation and pore } \\
\text { interconnectivity }\end{array}$ & $\begin{array}{l}{[101,102,10} \\
4-106]\end{array}$ \\
\hline Fibers & Electrospinning & $\begin{array}{l}\text { SF nanofibers are formed by the creation and } \\
\text { elongation of an electrified fluid jet and spun } \\
\text { into } 2 \mathrm{D} \text { and } 3 \mathrm{D} \text { scaffolds }\end{array}$ & $\begin{array}{l}\text { Tunable fiber } \\
\text { thickness and } \\
\text { porosity, good } \\
\text { interconnectivity }\end{array}$ & $\begin{array}{l}\text { Process depends on many } \\
\text { variables which hampers } \\
\text { reproducibility }\end{array}$ & $\begin{array}{l}{[121,122,12} \\
9]\end{array}$ \\
\hline $\begin{array}{l}\text { 3D printed } \\
\text { constructs }\end{array}$ & 3D printing, rapid prototyping & $\begin{array}{l}\text { CAD (computer-aided design) software can } \\
\text { be used to create } 3 \mathrm{D} \text { models and print them } \\
\text { with a } 3 \mathrm{D} \text { printer, the printed constructs can } \\
\text { be crosslinked by enzymes or high } \\
\text { temperatures }\end{array}$ & $\begin{array}{l}\text { Controllable micro- } \\
\text { and macro- } \\
\text { geometry, cells can } \\
\text { be encapsulated }\end{array}$ & Low resolution and porosity & $\begin{array}{l}{[123,125-} \\
127]\end{array}$ \\
\hline
\end{tabular}




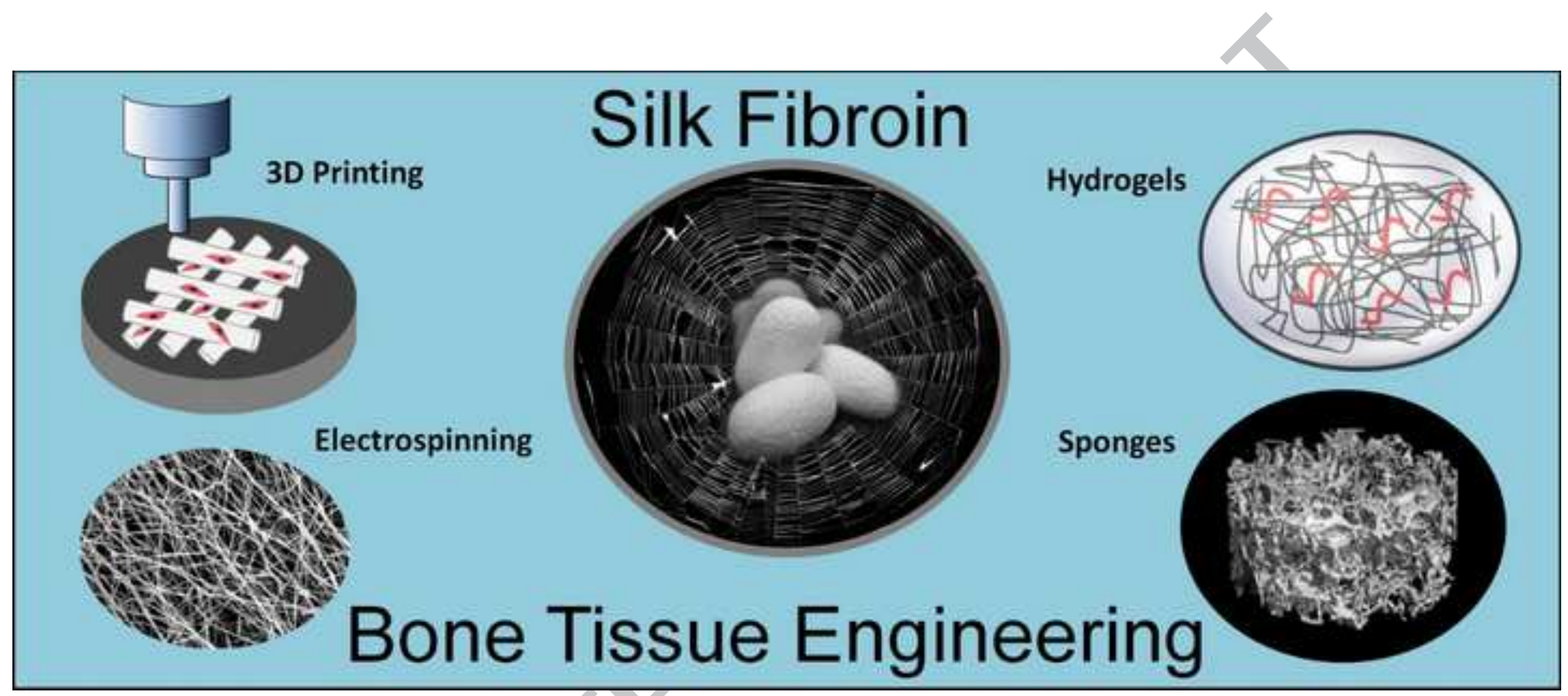

